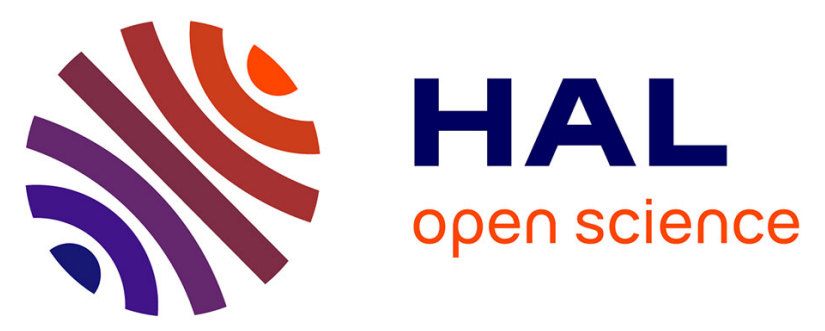

\title{
Predictive toxicology using systemic biology and liver microfluidic "on chip" approaches: Application to acetaminophen injury
}

Jean-Matthieu Prot, Andrei Bunescu, Bénédicte Elena-Herrmann, Caroline Aninat, Leila Choucha Snouber, Laurent Griscom, Florence Razan, Frédéric Y. Bois, Cécile Legallais, Céline Brochot, et al.

\section{To cite this version:}

Jean-Matthieu Prot, Andrei Bunescu, Bénédicte Elena-Herrmann, Caroline Aninat, Leila Choucha Snouber, et al.. Predictive toxicology using systemic biology and liver microfluidic "on chip" approaches: Application to acetaminophen injury. Toxicology and Applied Pharmacology, 2012, 259 (3), pp.270-280. 10.1016/j.taap.2011.12.017 . hal-00699551

\section{HAL Id: hal-00699551 https://hal.science/hal-00699551}

Submitted on 12 Mar 2014

HAL is a multi-disciplinary open access archive for the deposit and dissemination of scientific research documents, whether they are published or not. The documents may come from teaching and research institutions in France or abroad, or from public or private research centers.
L'archive ouverte pluridisciplinaire $\mathbf{H A L}$, est destinée au dépôt et à la diffusion de documents scientifiques de niveau recherche, publiés ou non, émanant des établissements d'enseignement et de recherche français ou étrangers, des laboratoires publics ou privés. 


\section{predictive toxicology using systemic biology and liver microfluidic "on chip" approaches: application to acetaminophen injury}

Jean-Matthieu Prot ${ }^{1}$, Andrei Bunescu ${ }^{2}$, Bénédicte Elena-Hermann ${ }^{2}$, Caroline Aninat $^{3}$, Leila Choucha Snouber ${ }^{1}$, Laurent Griscom ${ }^{5}$, Florence Razan ${ }^{5}$, Frederic Bois ${ }^{4}$, Cécile Legallais ${ }^{1}$, Céline Brochot ${ }^{4}$, Anne Corlu ${ }^{3}$, Marc Emmanuel Dumas ${ }^{2,6}$ and Eric Leclerc $^{1^{*}}$

${ }^{1}$ CNRS UMR 6600, Laboratoire de Biomécanique et Bio ingénierie, Université de Technologie de Compiègne, Centre de Recherche de Royallieu, BP20529, F-60205, France

${ }^{2}$ Université de Lyon, Centre de RMN à Très Hauts Champs, CNRS/ENS Lyon/ UCB Lyon 1, 5 rue de la Doua, F-69100 Villeurbanne, France

${ }^{3}$ Inserm, UMR991, Liver Metabolisms and Cancer, F-35033 Rennes; Université de Rennes 1, F-35043 Rennes,

${ }^{4}$ Institut National de l'Environnement Industriel et des Risques (INERIS), Unité Modèles pour l'Ecotoxicologie et la Toxicologie, Parc ALATA, BP2, F-60550 Verneuil en Halatte, France

${ }^{5}$ CNRS-UMR 8029, SATIE, Ecole Normale Supérieure de Cachan-Bretagne, Campus de Ker Lann, Bruz, France

${ }^{6}$ Department of Biomolecular Medicine, Faculty of Medicine, Imperial College London, South Kensington, London, SW7 2AZ, U.K

${ }^{*}$ Correspondence should be addressed to

Eric Leclerc

CNRS UMR 6600, Laboratoire de Biomécanique et Bioingénierie, Université de Technologie de Compiègne, France

Email: eric.leclerc@utc.fr

Phone: 33 (0)3 44237943 


\section{ABSTRACT}

We -analyzed transcriptomic, proteomic and metabolomic profiles of hepatoma cells cultivated inside a microfluidic biochip with or without acetaminophen (APAP). Without APAP, the results show an adaptive cellular response to the microfluidic environment, leading to the induction of anti-oxidative stress and cytoprotective pathways. In presence of APAP, calcium homeostasis perturbation, lipid peroxidation and cell death are observed. These effects can be attributed to APAP metabolism into its highly reactive metabolite, $\mathrm{N}$-acetyl-p-benzoquinone imine (NAPQI). . That toxicity pathway was confirmed by the detection of GSH-APAP, the large production of 2-hydroxybutyrate and 3-hydroxybutyrate, and methionine, cystine, and histidine consumption in the treated biochips. Those metabolites have been reported as specific biomarkers of hepatotoxicity and glutathione depletion in the literature. In addition, the integration of the metabolomic, transcriptomic and proteomic profiles collected allowed a more complete reconstruction of the APAP injury pathways. To our knowledge, this work is the first example of a global integration of microfluidic biochip data in toxicity assessment. Our results demonstrate the potential of that new approach to predictive toxicology.

Keywords: Microfluidic biochip, PDMS, liver tissue engineering, predictive toxicology, acetaminophen, transcriptomic, proteomic, metabolomic, biomarkers identification 
Superscripts in figures denote information confirmed at

(1) the gene, protein and metabolite levels,

(2) at the gene and protein levels,

(3) at the gene and metabolite levels,

(4) at the gene level,

(5) at the protein level,

(6) at the metabolite level.

Capital letters (G6PD ...) refer to genes symbols,

Chemical species in italics (as in g6pd or glucose-6-phosphate dehydrogenase...) refer to proteins or gene products,

Species in regular typeface (glucose...) refer to metabolites 


\section{INTRODUCTION}

Currently, in vitro cell culture methods for screening molecules mainly use plates (Petri dishes). Hepatocytes are considered to be among the most difficult type of cells to maintain in vitro in such systems. However it is essential use hepatocytes to understand and model metabolic phenomena (Guillouzo, 2008). That is why many tissue engineering processes have been developed to provide better environments for hepatocytes maintenance and development (Gebhardt, 2003; De Bartolo and Bader, 2001; Franklin and Yost, 2000; Guillouzo, 1998; De Kanter et al., 2002). Such environments must reproduce, as closely as possible, the in vivo conditions. Each one of the many in vitro hepatic culture systems currently available or in developement. can be used to answer toxicology or pharmacology questions, but they should be carefullyselected to be able to meet the pursued objectives.

One such in vitro system, bioartificial organs, seems to be a suitable method for reproducing the behavior of an organ or group of organs as well as the conditions of in vivo exposure. Bioartificial organs can now take advantage of recent developments in microtechnology to produce systems on a very small scale (Griffith and Naughton 2002; Powers et al., 2002; Sivaraman et al., 2005; Chao et al., 2010; Prot et al., 2011a; Baudoin et al., 2007; Novik et al., 2010; Baudoin et al., 2011). The cellular organization brought about by the micro-topography of these systems and their dynamic microfluidic culture conditionsappear to be key features for reproducing in vivo environments. These systems can function equally well in closed or open circuit modes, and thus simulate either chronic or acute tissue exposures.

A variety of approaches are available for describing the behavior and activity of cells as they react to stress, such as during exposure to a drug ). Transcriptomic, proteomic and metabolomic techniques are part of those (Boverhof et al., 2006). Genomic and transcriptomic methods can provide a near-complete analysis of the hereditary material of living organisms. Proteomicsassay all the proteins contributing to the structure and function of a cellular compartment, a cell, a tissue or a whole living organism (Figeys, 2004). Lastly, metabolomics, have also been proposed (Nicholson et al., 1999)to analyze concurrently all the small intermediate or final metabolites produced by chemical reactions taking place in cells or whole organisms. Metabolomics can potentially identify all the changes in biochemical composition and 
metabolism occuring after exposure to a given substance (Nicholson et al., 1999; Bugrim et al., 2004; Madalinski et al, 2009). All these "omic" approaches can therefore help understanding how a substance acts, at various levels, on an organism.

In our previous work, we showed that hepatocytes grown in microfluidic biochip maintain the activity of their main enzymes for xenobiotic metabolism (CYP1A, CYP2B, CYP3A4, several SULT and UGT sub-families and various phase 3 transporters such as MDR1 and MRP2) (Prot et al., 2011a, 2011b). In a study of the well-known hepatotoxic drug acetaminophen (APAP) in HepG2/C3a cells, we demonstrated that the use of biochips helps reproduce some of its in vivo reported mechanism of toxicity, such as GSH depletion and mitochondrial damage (Prot et al., 2011c). To investigate the potential of integrating systems biology and microfluidic biochip technology, we present here the interaction between the transcriptomic, proteomic and metabolomic profiles of liver cells cultivated in a microfluidic PDMS biochip and exposed to APAP. From the integration of those profiles we identified the activation some liver specific pathways related to drug metabolism. On the basis of our previous work we chose to work at $1 \mathrm{mM}$ APAP, a concentration at which perturbations of cell proliferation and hepatic metabolism are detectable (Prot et al., 2011b). APAP is metabolized by the cytochromes P450 CYP2E1, CYP1A2 and CYP $3 A 4$. Secondary metabolism is mediated by glutathione (GSH), sulfo and glucurono conjugations. Thanks to the microfluidic culture conditions, we were able to identify the major biological pathways involved in APAP toxicity to hepatocytes. Comparison with published in vivo studies finally lead to a similar interpretation of APAP toxicity mechanism, as opposed to the results that we obtained from the conventional plate analysis.

\section{RESULTS AND DISCUSSION}

Transcriptomic, proteomic and metabolomic analyses in microfluidic liver biochips

HepG2/C3A cell cultures in biochips were performed as described by Prot et al. (2011b). The morphology of adherent cells after $24 \mathrm{~h}$ at rest in the biochip is 
presented in Figures1A to $1 \mathrm{C}$ ). After flow perfusion was started, cells proliferated inside the biochip during $96 \mathrm{~h}$ the $72 \mathrm{~h}$ of perfusion (Fig.1D). As expected, the cells first created a confluent monolayer at the bottom of the culture micro-chambers. Afterwards, the cells proliferated up over the microstructures of the biochip forming a multilayer tissue (Fig. 1E). Calcein AM staining demonstrated the cell viability at the end of the cultures (Fig. 1F). After $1 \mathrm{mM}$ APAP treatment for $72 \mathrm{~h}$, the number of cells was reduced when compared to the untreated conditions in both biochips and plates (Figs $1 \mathrm{G}$ and $1 \mathrm{H}$ ). This reduction was higher in biochips than in plates (Figs. $1 \mathrm{G}$ and $1 \mathrm{H})$.

The statistical analysis of transcriptomic data discriminated global gene expression by separating the plate from the biochip groups for both untreated and treated APAP conditions (Fig 11). Culture in the microenvironment led to a total of 4012 genes showing statistically significant differences in expression (supplemental Table 1). APAP treatment in plate and in biochip significantly affected 1890 and 1121 genes respectively (supplemental Tables 2 and 3 ).

Proteomic analysis identified 86 proteins showing significant differences in concentration between the plate and biochip culture conditions, without APAP treatment (supplemental Table 4). At the protein level, APAP treatment had a statistically significant effect only in biochips, with 27 proteins affected (Fig 1J, supplemental Tables 5 and 6 ).

Finally, the cell media were collected and analyzed by ${ }^{1} \mathrm{H}$ NMR spectroscopy. 40 compounds were identified from the analysis of the NMR spectra (Table 1). That analysis was completed with measurements of albumin, urea, glucose, glutamine and ammonia levels by conventional bio-assays.

\section{Mechanistic interpretation of the effects of microfluidic cultures on HepG2/C3A cells without APAP treatment}

Knowledge-based metabolic pathway databases can be used to reveal the higher-order systemic operation of cells, organs and whole organisms. We identified significantly perturbed metabolic pathways by mapping transcriptomic, proteomic and metabolomic data signatures using the KEGG database (Kanehisa et al., 2010) and Ingenuity canonical pathways (Ingenuity® Systems). 
At first, integration between transcriptomic, proteomic and metabolomic data revealed an environmental effect due to the microfluidic culture conditions. We found an early adaptive response via the induction of Nrf-2 pathway. According to the Ingenuity pathway analysis (IPA), that pathway reached a $p$-value of $4 \times 10^{-8}$. Nrf-2 is a key transcriptional factor involved in the regulation of genes implied in cytoprotection against xenobiotic and oxidative injuries. In the liver, Nrf-2 activation lead to the induction of several genes and proteins regulating phase 1 andphase 2 biotransformation enzymes and phase 3 transporters. Network reconstruction, based on the direct links and the common elements of the metabolic canonical pathways, illustrates the activation of $\mathrm{Nrf}-2$ dependent pathways such as glutathione and methionine metabolism.We also found a higher consumption of histidine and methionine in biochips compared to plate cultures. A complete network was built using the pathways' common genes, proteins and metabolites as bridges (Fig. 2, Table 2). Our previous work has shown thatnecrosis and apoptosis occurred only to a small extent in the biochips (Prot et al. 2011a).

The fatty acid and lipid metabolism pathways were also highlighted by the profile integration via PPAR signaling, and butanoate and ketone metabolism (Fig. 3, Table 2) in coherence with numerous literature reports (Chapman, 2003; Cullingford et al., 2002). Steroids and cholesterol biosynthesis were also induced via the RXR and PXR pathways (Fig. 3, Table 2). However, biliary metabolism was not activated in our biochip cultures. Using the IPA, lipid metabolism perturbation reached a pvalue of $6 \times 10^{-7}$, with 140 genes involved. A specific biomarker of the fatty acid and lipid metabolism pathways induction in biochip, was the consistently high production of 3-hydroxybutyrate in the culture media.

Adaptation of the cell to the biochip microenvironment implies a high energy demand (Fig. 4, Table 2). Our analyses have shown an increase in glycolysis and glucogenesis. At the metabic level, we found higher glucose and glutamine consumptions correlated with higher ammonia, lactate, and glutamate productions. In addition, butanoate metabolism, an alternative energy source (ketones are generated by hepatic fatty acid $\beta$-oxidation when plasma insulin or insulin/glucagon ratios are low) (Fukao et al., 2004), was increased in the biochip. Butanoate metabolism is linked to the entry in the TCA cycle via succinate and Acetyl CoA 
productions (Table 2, Fig. 3 and 4). The degradation of several amino acids and metabolites (e.g., for choline, isoleucine, leucine, tyrosine and valine, Table 1) illustrated the request for TCA substrates. Interestingly, both lipid and glucose homeostasis were correlated in biochips with an induction of the insulin pathway, consistently with literature reports (Stephen et al., 1991; Yu et al., 2008). Thus, lipid metabolism was related to gene PI3KR controlling ACACA and FASN (upregulated and inducing lipogenesis) and controlling PDE3B (upregulated and repressing lipolysis). Glucose homeostasis was related to genes CBL, C3G, TC10 and EXO70, linked to glucose transporters and complexes involved in glucose uptake (Stephen et al., 1991).

In summary, intracellular analysis via the transcriptomic and proteomic profiles has shown that HepG2/C3A cells adapt to their new environment by inducing a cytoprotective mechanism, which induces a high energy demand. The extracellular biomarkers identified (such as the 3-hydroxybutyrate) in microfluidic biochip cultures confirmed both the cytoprotective response and the energy demand. In the following section, we will use this cellular stimulation for toxicity analysis.

\section{Mechanistic interpretations of the effects of APAP treatment on HepG2/C3A cells cultivated in microfluidic biochips}

The results of our study led to a mechanistic interpretation of APAP toxicity in biochips. In order to demonstrate the interest of our microfluidic model and its relevance to predictive toxicology, we have characterized the 1mM-APAP transcriptomic, proteomic metabolomic profiles in our liver biochips. APAP toxic metabolite NAPQI (N-acetyl-p-benzoquinone imine) is trapped by glutathione and excreted by the cells as GSH-APAP. That metabolites was detected by MS/MS in the biochip culture medium only and not in plate cultures (Table 1). Detoxification by sulfo-conjugation was evidenced by a higher production rate of Sult-APAP in biochips compared to plate cultures (Table 1). APAP pathway reconstruction using the integration of the transcriptomic, proteomic and metabolomics profiles led to the identification of a toxicity mechanism in biochips (Fig 5). Comparison the results obtained in biochips with and without APAP treatment, showed that APAP injury affected two pathways which were not detected in plates: 
- Lipid metabolism and peroxidation, $p$-value of $9.910^{-4}$, (via induction of the genes FAAH, PLA2G15, PPARD, DEGS1, FADS1, ACSBG1, ACSL1, AQP7, PASK, SMPD1, GPX2 , GPX3, and the production of Ita4h protein);

-Calcium homeostasis via the VDR/RXR activation pathway: $p$-value of $8 \times 10^{-2}$ (illustrated at the gene level through NCOR2, HSD17B2, NCOA1, HES1, PPARD and via the level of annexin A7, a calcium-dependent phospholipid binding protein, visinin and $S 100 P$ in the proteome).

In addition we found that, compared to untreated cases,APAP treatment led to

- DNA damage: pvalue $4.4 \times 10^{-4}$ (33 genes)

- Cell cycle arrest $p$-value $1 \times 10^{-5}$ (68 genes including SMAD3, SMAD7, p21)

- Cell death via apoptosis and necrosis, $p$-value $9.9 \times 10^{-4}$ (11 genes including casp 3 at the protein level)

- Reorganization of the cytoskeleton at the protein level via coronin, actin, keratin, tubulin perturbation.

Thus, we confirm that in biochips the specific signature of APAP toxicity at the gene and protein levels shows mechanisms similar to those reported in vivo (Ruepp et al., 2002). Furthermore, the APAP toxicity signaling pathway we reconstructed for biochips appears similar to the one built after in vivo data analysis, as shown by the comparison of Figs. 5 and 6 . To confirm the pathway reconstruction, we specifically analyzed mitochondrial membrane potential perturbation. The dissipation of the mitochondrial electrochemical potential gradient $(\Delta \Psi)$ and mitochondrial dysfunction following APAP treatment was confirmed by JC-1 staining, illustrating APAP toxicity after $24 \mathrm{~h}$ of perfusion (Fig 7 ). In addition, the higher sensitivity of cells in biochip, compared to plate culture conditions, was confirmed by cell counts and measures of cell cycle reparation in our previous work (Prot et al., 2011c).

\section{Identification of specific APAP toxicity biomarkers in biochips}

The results of metabolomic profiling led to the identification of specific biomarkers of the APAP injury related to hepatotoxicity and glutathione depletion. Table 1 shows the production and consumption of the molecules detected in the 
culture medium. Using those data we were able to reconstruct a network of pathways of glutathione depletion in biochips (Fig 8).

APAP injury is related to glutathione consumption and depletion via the formation of NAPQI. The cellular adaptation step to the micro-environment induced defense mechanism involving cytochrome P450. APAP biotransformation is thereforeenhanced in biochips, leading to a higher level of NAPQI production when compared to plate cultures. The specific augmentation of 2-hydroxybutyrate production and consumption of cysteine, histidine and methionine in biochips are directly correlated with the glutathione pathway and APAP detoxification mechanism. 2-hydroxybutyrate, under metabolic stress, is released as a byproduct when cystathionine is cleaved to cysteine before its incorporation into glutathione (Gall et al. 2010). Furthermore, the glutathione precursor S-adenosylmethionine (SAM) is formed by combining methionine with ATP to synthesize cysteine, which is used to produce glutathione. The higher level of those compounds in the APAP treated biochips culture medium demonstrated a higher APAP toxicity in microfluidic conditions. However, we did not find any taurine, creatine or ophtalmic acid accumulation in the culture media of the biochips. Those molecules, related to glutathione production, were detected in urine analysis and in liver extracts from in vivo studies. They have also been reported as APAP toxicity biomarkers (Beger et al. 2010; Soga et al., 2006).

Furthermore, increased levels of 3-hydroxybutyrate in the APAP treated biochip cultures demonstrated an intense lipid metabolism through the ketone degradation pathway. Major changes in 3-hydroxybutyrate concentration, related to the metabolism of plasma lipids, occurs when tissue are exposed to stress (Fukao et al., 2004). A high increase of urinary 3-hydroxybutyrate has been reported as an early biomarker of toxicity (such as in nephrotoxicity, Boudonck et al., 2009, or during surgical trauma, Teague et al., 2007).

In addition to the metabolomic biomarkers reported in Fig.8 and Table 1, the activation of glutathione pathway in the APAP treated biochips was correlated with the induction of the GGT7, G6PD, GPX2, GPX3, GSTm2/4, GSTT2 genes and by the g6pd and txnrd1 protein production compared to untreated biochips. We also found a modification of CBS, DAO, GATM, BDMGTH, SHMT gene expressions and of the strap and pp2ca proteins in the serine, glycine and threonine pathway; and a modification of the level of expression of the GATM, DAO, P4HA, PYCR, PRODH2 
genes in the arginine-proline pathway. Amino acid biotransformation results in an intense TCA cycle activation (Fig 8). That was illustrated by an important consumption of glutamine, glucose, fructose and pyruvate, coupled with ammonium and lactate production when compared to untreated cultures. Correlation between metabolomic and transcriptomic profiles in APAP toxicity has been reported in vivo using mouse in which APAP affected the lipid content and glucose homeostasis, and were correlated to changes in liver energy metabolism (Coen et al., 2004). Our findings are consistent with these in vivo observations.

Our results demonstrated an intense activity of the glutathione pathway due to glutathione depletion for NAPQI elimination. That was in agreement with GSH-APAP conjugation found only in biochip (Table 1). Biomarkers of the metabolic status of HepG2/C3A cells in microfluidic biochips were identified. They confirmed the detoxification processes and the related energy demand pointed at by the transcriptomic and proteomic analysis. That result is essential as it demonstrates the potential of microfluidic biochips coupled to metabolomics to provide a functional cell response in agreement with the intracellular information obtained at the gene and protein levels. We believe that the microfluidic biochip can behave as a "biosensor" system when combined with ${ }^{1} \mathrm{H}$ NMR-based metabolomic footprinting of organ culture media, and that it will be useful as a high-throughput small-molecule screening approach.

\section{Systems biology and predictive toxicology on chip.}

To understand the mechanisms connecting molecular and cellular changes to tissue level properties, microarray analyses of large scale changes in gene expression can be studied, as shown in the present work. A significant focus of such studies is to discover how individual genes are integrated into specific regulatory or signaling networks and which pathways are significantly altered by treatments. However, static lists of differentially expressed genes, proteins or molecules will not give us a complete access to a systemic and dynamic understanding of physiological processes or of toxicity. Yet, we should aim for such an understanding if we want to replace in vivo experiments by a mechanistic and predictive toxicology (Chiu et al., 2010). Mathematical descriptions of the liver cells and tissue, coupled to 
physiologically based pharmacokinetic modeling (lerapetritou et al., 2009; Park et al., 2010), have the potential to integrate liver biochip cellomic data for a quantitative, dynamic and hierarchical description of the body handling of endogenous and exogenous substances. A shorter term goal is to develop methods for checking the consistency of individual pathways activations. For example, our results point to the activation of multiple metabolic pathways (such as drug and lipid metabolism related pathways and the glutathione pathway), but those were assessed individually and semi-quantitatively. A validation of the quantitative coherence of these findings would require pathways linking and an understanding (at least partial) of the sign of the interactions between pathway nodes. We are currently working on both of those short-term and long-term goals.

Alternative methods for predictive toxicology should first be standardized and validated to become acceptable to regulatory authorities. In terms of molecular phenotyping, the comprehensive analysis of endogenous low molecular-weight metabolites, or metabonomics (Nicholson et al., 1999; 2002), is a powerful tool for characterizing variations in the concentration of such compounds in biofluids or organs in response to drug treatments (Clayton et al., 2006), but also to pathophysiology (Dumas et al., 2006) or genetic polymorphisms (Dumas et al., 2007). Our results demonstrate that we were able to extract specific signatures of the culture mode and cellular environment in plates and in biochips. Furthermore, in vivo hepatotoxic and GSH depletion related biomarkers were identified in the APAP treated biochip cultures. Despite the fact that we did not work with primary hepatocytes which would probably better reflect in vivo toxicity, our results are encouraging for an eventual application of liver microfluidic biochips as a new tool in xenobiotic screening applications.

\section{Conclusion}

In summary, we have characterized the transcriptomic, proteomic and metabolomic profiles of $\mathrm{HepG} 2 / \mathrm{C} 3 \mathrm{~A}$ cells cultivated in a microfluidic environment. Profile integration demonstrated a cytoprotective cell response, induced by the microfluidic biochip conditions. . The toxicological response of HepG2/C3A cells in biochips cultures to APAP injury could be correlated to glutathione depletion and to the apparition of NAPQI. That led to a perturbations of calcium homeostasis via 
mitochondrial perturbations, to lipid peroxidation and to cell death. Pathway reconstruction resulted in a metabolic map that can be successfully superimposed to pathways identified from in vivo data. In addition, we also illustrated the applicability of an exploratory spectroscopic phenotyping assay to identify metabolic biomarkers of xenobiotics exposure and toxicological insults in mammalian cells thanks to microfluidic cultures. We found that 2-hydroxybutyrate production was a biomarker of APAP treatment in our study. It was correlated with a high production of 3hydroxybutyrate and with a high consumption of cystine, histidine and methionine in the treated biochips. The "systems biology on chip' approach we propose has the potential to allow serendipitous discovery of cell-specific dose-response markers, while reducing the use of laboratory animals. Finally, our finding provide an important insight into the use of microfluidic biochips as new tools in biomarker research in therapeutic drug studies and predictive toxicity investigations. 


\section{MATERIALS AND METHODS SECTION:}

\section{Microfluidic Biochip and cell cultures.}

To fabricate the biochips, we used the Polydimethylsiloxane polymer (PDMS) (Dow Corning, Sylgard 184). This material has high gas permeability, which allows oxygenation of cells in culture. PDMS is transparent, and the biochips allow optical observations coupled with real time analysis of the cells' morphology. The fabrication details, based on replica molding and PDMS plasma bonding, are reported in Baudoin et al. (2011).

The hepatocellular carcinoma-derived cell lines HepG2/C3A were used as liver cell models. The cells were chosen for to their more stable morphotype compared to primary cells. That helps for parallel studies needed for biological characterization. The cells were maintained in a culture medium containing Minimal Essential Medium (MEM, Gibco), $2 \mathrm{mM}$ L-Glutamine, 0.1mM non-essential amino acids, $1.0 \mathrm{mM}$ sodium pyruvate, $10 \%$ of fetal bovine serum, and penicillinstreptomicin (100 units $/ \mathrm{mL}$ ). The batch cultures were performed in T75 flasks (Falcon, Merk Eurolab, Strasbourg, France) using $15 \mathrm{~mL}$ of medium. The cells were used between the $10^{\text {th }}$ and $30^{\text {th }}$ passages.

The biochips were coated with fibronectin for $40 \mathrm{~min}(10 \mu \mathrm{g} / \mathrm{mL})$ before carrying out the cultures. The cells were cultivated in the biochips under static conditions during $24 \mathrm{~h}$ for adhesion. Then, a flow rate of $10 \mu \mathrm{L} / \mathrm{min}$ of medium was applied for $72 \mathrm{~h}$. All dynamic experiments were performed within those $96 \mathrm{~h}$ of cultures.

We compared cellular activity between the biochips and 12-well tissue culture plates (Becton Dickinson, Petri static conditions). Those plates were first covered by $0.5 \mathrm{~mL}$ of PDMS and then coated with fibronectin as were the biochips .

The cells were seeded at a density of $2.5 \times 10^{5}$ cells $/ \mathrm{cm}^{2}$ in plates and in biochips (this corresponds to $5 \times 10^{5}$ cells/biochip). For APAP treatment, $1 \mathrm{mM}$ of APAP was loaded in the biochip circuit and plates before the start of perfusion.

\section{RNA extraction, hybridisation on Affymetrix chips and microarray analyses}

We have precisely describedthe microarray procedure in Prot et al. (2011a). Briefly, after RNA extraction, quality was checked with a Bioanalyzer 2100 (Agilent Technologies, Massy, France). RIN were ranging between 9.3 and 10. The raw data 
(affymetrix .cel files) were obtained using affymetrix Genechip operating software. All .cel files were analysed using the expression console from affymetrix in order to monitor the microarray quality with different control metrics. Data were normalised by Robust Multichip Averaging (RMA) in order to remove handling errors. A principal component analysis (PCA) was applied to the global expression data using the $R$ software (http://www.R-project.org). Lists of the genes extracted after $t$-test separation at the $0.01 p$-value. The corresponding lists were fed to Ingenuity Pathway Analysis to obtain biological functions, top network and gene ID. In the present analysis,no (???) fold change filtration was done (on contrary to our previous analysis using this set of data). The GEO access of the data is GSE27420.

\section{Proteomic analysis}

The detailed protocol of the proteomic procedure was presented previously (Prot et al., 2011c). Briefly, the cells were collected and the protein concentration determined by a Bradford method. The proteins were labelled with a CyDye DIGE fluor kit. Equilibrated strips were placed onto homemade polyacrylamide gels (8$18 \%$ ), overlaid with agarose solution and electrophoresis was performed simultaneously in a Ettan-DALT II system (GE Healthcare) at $2.5 \mathrm{~W} / \mathrm{gel}$ at $15^{\circ} \mathrm{C}$ until the bromophenol blue dye reached the bottom of the gels. Gels were scanned using a Typhoon 9400 (GE Healthcare) with a resolution set at $100 \mu \mathrm{m}$. Image analysis were performed by Decyder software suite (GE Healthcare, version 5.02) which allow the comparison of the different combination corresponding to the experimental conditions.

Spots of interest was analysed using a MALDI-TOF-TOF 4800 mass spectrometer (Applied Biosystems). Database searching was carried out using Mascot version 2.2 (MatrixScience, London, UK) via the GPS explorer software (ABI) version 3.6 combining $\mathrm{MS}$ and MS/MS interrogations on Human proteins from Swissprot databank, 18138 entries, (Swissprot databank: 333445 sequences; 120048673 residues, www.expasy.org). Positive identification was based on a Mascot score above the significance level (i.e. $<5 \%$ ). The reported proteins were always those with the highest number of peptide matches.

Down or up-expressed proteins of the different experimental conditions (microfluidic biochip, plates) were retained if protein spot fold change was larger than +1.5 or smaller than -1.5 and had a Student's $t$-test $p$-value less than 0.05 . PCA was 
performed on the global proteins distribution to see change of repartition according the experimental conditions.

\section{H NMR spectroscopy of cell media.}

Culture media samples were prepared using $350 \mu$ of cell medium mixed with $200 \mu$ of a phosphate buffer $\mathrm{pH} 7.4\left(50 \% \mathrm{D}_{2} \mathrm{O} / \mathrm{H}_{2} \mathrm{O}\right.$ ( $\left.\mathrm{vol} / \mathrm{vol}\right), 1 \mathrm{mM}$ trimethylsilyl propionate-d4 (TSP)). All NMR experiments were carried out on a Bruker Avance III spectrometer operating at $800 \mathrm{MHz}\left({ }^{1} \mathrm{H}\right.$ resonance frequency) using a standard 5$\mathrm{mm}$ TXI probe at $300 \mathrm{~K}$. Conventional ${ }^{1} \mathrm{H}$ 1D NMR spectra were measured using the NOESY pulse sequence with water presaturation during the $2 \mathrm{~s}$ recycle delay, and a $100 \mathrm{~ms}$ mixing time. For each sample, 128 free induction decay (FID) were collected with 40,960 data points with an acquisition time of 1,7 s. The FIDs were multiplied by an exponential weighting function corresponding to a line broadening of $0.3 \mathrm{~Hz}$ and zero-filled before Fourier transformation, zero order phase correction and manual baseline adjustment.

\section{NMR metabolites assignment and quantification}

Identification of the metabolites from the culture medium was carried out from the 1D NMR data using the software Chenomx NMR Suite 7.0 (Chenomx Inc., Edmonton, Canada). Assignment of additional observed metabolites was confirmed from the analysis of 2D ${ }^{1} \mathrm{H}-{ }^{1} \mathrm{H}$ TOCSY and ${ }^{1} \mathrm{H}-{ }^{13} \mathrm{C}$ HSQC NMR spectra recorded with standard parameters. Metabolites concentrations were determined by manual fitting of the proton resonance lines for the compounds available in the Chenomx database. The TSP linewidth used in the reference database was adjusted to the width of one component of the alanine doublet. The reference concentration was set after automatic fitting of the TSP resonance.

\section{Biochemical assays}

Glucose and glutamine consumption, and ammonia and albumin production, were measured after $96 \mathrm{~h}$ of culture. The protocols have been described in detail previously (Baudoin et al. 2011). Briefly, glucose, glutamine and ammonia 
concentrations were measured using a Konelab 20 biochemical analyzer (Thermo Electron Corporation). Albumin synthesis was measured by means of an ELISA sandwich technique (anti Human Albumin IgG, Cappel; anti Human Albumin IgG coupled with peroxydase, Cappel). The JC-1 Mitochondrial Membrane Potential Kit was used as an indicator of cell death according to the manufacturer's instructions in order to assess the $\Delta \Psi$ mitochondrial gradient and mitochondrial dysfunction. Valinomycin, which dissipates the mitochondrial potential, was used as a positive control. The red aggregated JC-1 represents intact mitochondria and the green fluorescence of the monomeric $\mathrm{JC}-1$ represents disrupted mitochondria. The ratio of red to green fluorescent intensity was quantified with the CellProfiler software (Carpenter et al., 2006).

\section{APAP Metabolism activities}

APAP metabolites were measured by LC/MS/MS. The method is introduced in our previous work (Prot et al., 2011c). Our LC-MS/MS system is composed of Dionex Ultimate 3000 capillary HPLC with a Famos injector and a UV UVD 3000 detector. The HPLC chain is coupled with a Triple Quad WATERS (micromass) Quatro micro mass spectrometer. The analytes were detected by MRM (Multiple Reaction Monitoring) in positive ion mode. The areas obtained for Glutathione-APAP (MW: 457 $\mathrm{g} / \mathrm{mol}$ ), Glucurono-APAP (MW: $328 \mathrm{~g} / \mathrm{mol}$ ), and Sulfo-APAP (MW: $232 \mathrm{~g} / \mathrm{mol}$ ) were compared to a known quantity of each standard (SIGMA) making possible a semi-quantitative dosage. 


\section{ACKNOWLEDGEMENTS}

Jean Matthieu Prot received a grant from the CNRS and from the "conseil régional de Picardie". The project was supported by the foundation of the University of Technology of Compiègne "La Fondation UTC pour l'innovation" via the "puce à cellule project". The project was also supported by the ANR PCV 2007 program via the " $\mu$ HepaReTox" project and by the ANR CP2D 2007 program via the SysBioX project. The SULT-APAP and GSH-APAP was measured by Geoffrey Madalinski and Eric Ezan from CEA Saclay, laboratoire d'étude du métabolisme du médicament. The microarrays of the transcriptomic analysis were performed by Franck Letourneur from Institut Cochin, Paris. The proteomic analysis was supervised by Philippe Chafey at the Institut Cochin, Paris. We finally thank Morgane Le Gall and Guilhem Clary from Plateforme Electrophorese Bidimensionnelle, UMR 8104, for their technical support in 2D Dige analysis.

\section{AUTHORS CONTRIBUTIONS}

Jean Matthieu Prot was performed the liver biochip experiments and data analysis as part of his Ph.D. thesis work.

Leila choucha Snouber was involved in some of the biochip experiments.

Andrei Bunescu, Benedicte Elena-Hermann, Marc Emmanuel Dumas were involved in the metabolomic analysis.

Anne Corlu and Caroline Aninat were involved in the transcriptomic analysis and in the liver biology analysis.

Céline Brochot and Frederic Bois were involved in the data analysis.

Laurent Griscom and Florence Razan were involved in the biochip fabrication. 
Eric Leclerc was project leader.

All authors contributed to the paper redaction.

\section{CONFLICTS OF INTERESTS}

The authors have no conflict of interest to report..

\section{REFERENCES}

Baudoin R, Corlu A, Griscom L, Legallais C, Leclerc E (2007) Trends in the development of microfluidic cell biochips for in vitro hepatotoxicity. Toxicology in vitro 21:535-544

Baudoin R, Griscom L, Prot JM, Legallais C , Leclerc E (2011) Behavior of HepG2/C3A cell cultures in a microfluidic bioreactor, Biochemical Engineering Journal, 53:172-181

Beger R, Sun J, Schnackenberg L (2010) Metabolomics Approaches for Discovering Biomarkers of Drug-induced Hepatotoxicity and Nephrotoxicity. Toxicology and Applied Pharmacology 243:154-166

Bhogal N, Grindon C, Combes R, Balls M (2005) Toxicity testing: creating a revolution based on new technologies. Trends in biotechnology. 23:299-307.

Blaauboer BJ, Andersen ME. (2007) The need for a new toxicity testing and risk analysis paradigm to implement REACH or any other large scale testing initiative. Archives of toxicology 81:385-7.

Boudonck K, Mitchell M, Nemet L, Keresztes L, Nyska A, Shinar D, Rosenstock M, (2009) Discovery of Metabolomics Biomarkers for Early Detection of Nephrotoxicity, Toxicologic Pathology 37: 280-292

Boverhof DR, Burgoon LD, Tashiro C, Sharratt B, Chittim B, Harkema JR, et al. (2006) Comparative toxicogenomic analysis of the hepatotoxic effects of TCDD in Sprague Dawley rats and C57BL/6 mice Toxicol Sci. 94:398-416.

Carpenter AE, Jones TR, Lamprecht MR, Clarke C, Kang IH, Friman O, Guertin DA, Chang JH, Lindquist RA, Moffat J, Golland P, Sabatini DM (2006) CellProfiler: image analysis software for identifying and quantifying cell phenotypes. Genome Biology 7:100-111 
Chao P, Maguire T, Novik E, Cheng KC, and Yarmush ML (2009) Evaluation of a microfluidic based cell culture platform with primary human hepatocytes for the prediction of hepatic clearance in human, Biochemical pharmacology 78:625-632 Chapman MJ (2003) Fibrates in 2003: therapeutic action in atherogenic dyslipidaemia and future perspectives. Atherosclerosis 171:1-13.

Chiu WA, Euling SY, Siegel Scott C, Subramaniam RP (2010) Approaches to advancing quantitative human health risk assessment of environmental chemicals in the post genomic era, Toxicology and Applied Pharmacology, in press

Clayton, T.A. et al. Pharmaco-metabonomic phenotyping and personalized drug treatment. Nature 440, 1073-1077 (2006).

Coen M, Ruepp SU, Lindon JC, Nicholson JK, Pognan F, Lenz EM, Wilson ID (2004) Integrated application of transcriptomics and metabonomics yields new insight into the toxicity due to paracetamol in the mouse. Journal of Pharmaceutical and Biomedical Analysis 35:93-105.

Cullingford TE, Dolphin CT and Sato H (2002) The peroxisome proliferator-activated receptor alpha-selective activator ciprofibrate upregulates expression of genes encoding fatty acid oxidation and ketogenesis enzymes in rat brain. Neuropharmacology 42:724-730.

De Bartolo L, Bader A (2001) Review of a flat membrane bioreactor as a bioartificial liver. Ann. Transplant. 6:40-46

De Kanter R, Monshouwer M, Meijer D, Groothuis G. (2002) Precision-cut organ slices as a tool to study toxicity and metabolism of xenobiotics with special reference to non-hepatic tissues. Adapt. Curr. Drug Metabol. 3:39-59.

Dumas, M.E. et al. (2006) Metabolic profiling reveals a contribution of gut microbiota to fatty liver phenotype in insulin-resistant mice. Proc Natl Acad Sci U S A 103: 12511-12516

Dumas, M.E. et al. (2007) Direct quantitative trait locus mapping of mammalian metabolic phenotypes in diabetic and normoglycemic rat models. Nat Genet 39:666672

Fiehn O, Kopka J, Dörmann P, Altmann T, Trethewey RN, Willmitzer L (2000) Metabolite profiling for plant functional genomics. Nat. Biotechnol. 18, 1157-1161

Figeys D (2004) Combining different 'omics' technologies to map and validate protein-protein interactions in humans. Briefings in functional genomics \& proteomics 2:357-65.

Franklin MR, Yost GS. (2000) Biotransformation: a balance between bioactivation and detoxification. In: Williams, P.L., James, R.C., Roberts, S.M. (Eds.), Principles of 
Toxicology: Environmental and Industrial Applications. John Wiley \& Sons, New York, NY, 57-86

Fukao T, Lopaschuk GD and Mitchell GA (2004) Pathways and control of ketone body metabolism: on the fringe of lipid biochemistry. Prostaglandins Leukot Essent Fatty Acids 70:243-251.

Gall W, Beebe K, Lawton K, Adam KP, Mitchell M, Nakhle P, Ryals J, Milburn M, Nannipieri M, Camastra S, Natali A, Ferrannini E, (2010) a-Hydroxybutyrate Is an Early Biomarker of Insulin Resistance and Glucose Intolerance in a Nondiabetic Population, PLoS One 5:e10883

Gebhardt R, Hengstler JG, Muller D, Glockner R, Buenning P, Laube B, Schmelzer E, Ullrich M, Utesch D, Hewitt N, Ringel M, Hilz BR, Bader A, Langsch A, Koose T, Burger HJ, Maas J, Oesch F. (2003). New hepatocyte in vitro systems for drug metabolism: metabolic capacity and recommendations for application in basic research and drug development, standard operation procedures. Drug Metab Rev. 35:145-213

Ghanem, A. and Shuler, M. L. (2000). "Combining cell culture analogue reactor designs and PBPK models to probe mechanisms of naphthalene toxicity." Biotechnology Progress 16: 334-345.

Gibney M, Walsh M, Brennan L, Roche H, German B and van Ommen B. (2005) Metabolomics in human nutrition: opportunities and challenges, American Journal of Clinical Nutrition, 82, 497-503

Hengstler, J. G., Foth, H., Kahl, R., Kramer, P. J., Lilienblum, W., Schulz, T. and Schweinfurth, H. (2006). The REACH concept and its impact on toxicological sciences. Toxicology 220: 232-239.

Greim H, Arand M, Autrup H, Bolt HM, Bridges J, Dybing E, Glomot R, Foa V, Schulte-Hermann R (2006) Toxicological comments to the discussion about REACH Arch. Toxicol., 80: 121-124.

Guillouzo A. (1998) Liver cell models in in vitro toxicology. Environ Health Respect. 106:511-532

Guillouzo A. (2008) New perspectives in the use of human hepatocytes in the preclinical drug development process. Ann Pharm Fr. 66:288-295

Griffith L and Naughton G (2002) Tissue Engineering-current challenges and expanding opportunities, Science 295:1009-1014

Hartung T and Rovida C, (2009) Chemical regulators have overreached, Nature 460: 1080-1081

lerapetritou MG, Georgopoulos PG, Roth CM, Androulakis IP (2009) Tissue-Level 
Modeling of Xenobiotic Metabolism in Liver: An Emerging Tool for Enabling Clinical Translational Research. Clinical and Translational Science 2: 228-237.

Kanehisa, M., Goto, S., Furumichi, M., Tanabe, M., and Hirakawa, M (2010) KEGG for representation and analysis of molecular networks involving diseases and drugs. Nucleic Acids Res. 38: 355-360.

Novik E, Maguire TJ, Chao P, Cheng KC, Yarmush ML (2010) A microfluidic hepatic coculture platform for cell-based drug metabolism studies. Biochemical Pharmacology 79:1036-1044.

Nicholson JK., Connelly J, Lindon JC and Holmes E (2002) Metabonomics: a platform for studying drug toxicity and gene function. Nat Rev Drug Discov 1:153-161 Nicholson JK, Lindon JC and Holmes E (1999) 'Metabonomics': understanding the metabolic responses of living systems to pathophysiological stimuli via multivariate statistical analysis of biological NMR spectroscopic data. Xenobiotica 29:1181-1189 Madalinski G, Godat E, Alves S, Lesage D, Genin E, Levi P, Labarre J, Tabet JC, Ezan E, Junot C. (2008) Direct introduction of biological samples into a LTQ-Orbitrap hybrid mass spectrometer as a tool for fast metabolome analysis. Anal Chem. 80: 3291-303

Park S, Kim SHJ, Ropella GEP, Robert MS, Hunt CA (2010) Tracing multiscale mechanisms of drug disposition in normal and diseased livers. Journal of Pharmacology and Experimental Therapeutics 334:124-136.

Powers MJ, Janigan D, Wack KE, Baker, Stolz DB, Griffith L (2002) Functional behavior of primary Rat liver cells in a three-dimensional perfused microarray bioreactor. Tissue Engineering 8:499-508

Prot JM, Aninat C, Griscom L, Razan F, Brochot C, Guguen Guillouzo C, Legallais C, Corlu A, Leclerc E (2011a) Improvement of HepG2/C3a cell functions in a microfluidic biochip, Biotechnology and Bioengineering, 108:1704-1715

Prot JM, Videau O., Brochot C., Legallais C., Benech H., Leclerc E. (2011b), A cocktail of metabolic probes demonstrates the relevance of primary human hepatocyte cultures in a microfluidic biochip for pharmaceutical drug screening, Int J. of Pharmaceutics, 408: 67-75

Prot JM, Briffaut AS, Letourneur F, Chafey P, Merlier F, Grandvalet Y, Legallais C, Leclerc E (2011c), Integrated proteomic and transcriptomic investigation of the acetaminophen toxicity in liver microfluidic biochip, PlosOne, 6, 21268- 21278

Ruepp S., Tonge R., Shaw J., Wallis N, Pognan F (2002) Genomics and Proteomics Analysis of Acetaminophen Toxicity in Mouse Liver. Toxicological Sciences. 65:135150 
Sheikh-Bahaei S, Kim SHJ, Sheikhbahaei S, Hunt CA (2009) Understanding the Role of Liver Zonation in Toxin Elimination. International Journal of Intelligent Control and Systems 14: 33-40.

Sivaraman A, Leach JK, Townsend S, lida T, Hogan BJ, Stolz DB, Fry R, Samson LD, Tannenbaum SR, Griffith LG. 2005. A Microscale In Vitro Physiological Model of the Liver: Predictive Screens for Drug Metabolism and Enzyme Induction. Current Drug Metabolism 6:569-592

Stephens JM, Pekala PH (1991) Transcriptional repression of the GLUT4 and C/EBP genes in 3T3-L1 adipocytes by tumor necrosis factor-alpha, J Biol Chem. 266:2183945.

$\underline{\text { Soga T, Baran R }}$, Suematsu M, Ueno Y, Ikeda S, Sakurakawa T, Kakazu Y, Ishikawa I, Robert M, Nishioka T, Tomita M (2006) Differential metabolomics reveals ophthalmic acid as an oxidative stress biomarker indicating hepatic glutathione consumption. J Biol Chem. 281:16768-76

Son D., Satsu H., Shimizu M., (2005) Histidine inhibits oxidative stress and TNF alpha induced interleukin 8 secretion in intestinal epithelial cells, FEBS Letters $\mathbf{5 7 9}$, 4661-4677

Teague CR, Dhabhar FS, Barton RH, Beckwith-Hall B, Powell J, Cobain M, Singer B, McEwen BS, Lindon JC, Nicholson JK, Holmes E, (2007) Metabonomic studies on the physiological effects of acute and chronic psychological stress in SpragueDawley rats. J. Proteome Res. 6:2080-93.

Yu X, Pandey SK, Booten SL, Murray SF, Monia BP, Bhanot S (2008) Reduced adiposity and improved insulin sensitivity in obese mice with antisense suppression of 4E-BP2 expression, Am J Physiol Endocrinol Metab. 294:E530-9 


\section{FIGURES AND TABLES LIST}

Table 1: Cell production (+) and consumption (-) in $\mathrm{nmol} / \mathrm{h} / 10^{6}$ cells of the compounds detected by $\mathrm{H}-$ NMR and measured in the culture medium. The data represent the situation between $48 \mathrm{~h}$ and $96 \mathrm{~h}$ of cultures in plates or biochips (mean and SD, $n=3+9=12$ ), --- denotes data below the limit of ${ }^{1} \mathrm{H}-\mathrm{RMN}$ detection $(1 \mu \mathrm{M}),{ }^{*}$ denotes values measured by conventional biochemical assays and kits, ${ }^{* *}$ denotes products detected by MS/MS; $(\mu)$ denotes arbitrary unit $A U, £$ denotes data in $n g / h / 10^{6}$ cells

Table 2: List of genes, proteins and metabolites affected by the microfluidic conditions when compared to plate cultures and involved in the network reconstruction of Figs 2 and 3. Underlined genes were confirmed by RTqPCR (Prot et al., 2011a)

Figure 1: (A) Microfluidic PDMS network; (B) Cell chamber before cell inoculation; (C) Cell after adhesion; (D) Cell after 96h of cultures without APAP; (E) SEM view of the cell multilayers in the biochip after $96 \mathrm{~h}$ of culture without APAP; $(\mathrm{F})$ viability of the cells after $96 \mathrm{~h}$ of culture without APAP ; (G) Cells after $96 \mathrm{~h}$ of culture including $72 \mathrm{~h}$ of APAP treatment; $(\mathrm{H})$ Cell number decreases in biochip and plate with $1 \mathrm{mM}$ of APAP after $96 \mathrm{~h}$ of cultures including $72 \mathrm{~h}$ of treatment; (I) Results of the PCA of the transcriptomic analysis; $(\mathrm{J})$ Results of the PCA of the proteomic analysis; circles denotes plate data, triangles denote biochip data, black symbols are control data, white symbols are APAP data.

Figure 2: Network reconstruction according to the integration of the transcriptomic, proteomic and metabolomic profiles after $96 \mathrm{~h}$ of cultures describing the HepG2/C3A response to the microfluidic biochip conditions. Superscripts denote information from table 2 and extracted at (1) the genes, proteins and metabolites levels, (2) at the gene and protein levels, (3) at the genes and metabolites levels, (4) at the genes level. Reported genes, proteins and metabolites are common element used to bridge the pathways; upward arrows denote gene induction, protein and metabolite production;downward arrows denote gene down regulation, protein and metabolite consumption. Capital letters (e.g. CBS ...) denote affected genes in the pathway, small italic letters denotes proteins (e.g. strap...) related to the pathway.

Figure 3: Network reconstruction according the integration of the transcriptomic, proteomic and metabolomic profiles after $96 \mathrm{~h}$ of culture of the HepG2/C3A in microfluidic biochips focusing on the lipids, fatty acids and steroids metabolism. Superscripts denote information from table 2 extracted at (1) the genes, proteins and metabolites levels, (2) at the gene and protein levels, (3) at the genes and metabolites levels, (4) at the genes level. Reported genes, proteins and metabolites are common 
element used to bridge the pathways; upward arrows denote gene induction, protein and metabolite production; downward arrowsdenote gene down regulation, protein and metabolite consumption.

Figure 4: Network reconstruction according the integration of the transcriptomic, proteomic and metabolomic profiles after $96 \mathrm{~h}$ of culture and related to the HepG2/C3A energy demand. Superscripts denote information from table 2 extracted at (1) the genes, proteins and metabolites levels, (2) at the gene and protein levels, (3) at the gene and metabolites levels, (4) at the genes level. Reported genes, proteins and molecules are common element used to bridge the pathways; upward arrows denote gene induction, protein and metabolite production; downward arrowsdenote gene down regulation, protein and metabolite consumption.

Figure 5: Mechanistic network reconstruction of the 1mM-APAP toxicity in the HepG2/C3a after 96h of culture in biochip based on the in vivo representation of Ruepp et al. 2002; Superscripts denote information confirmed at (1) the genes, proteins and metabolomics levels, (2) at the gene and protein levels, (3) at the gene and metabolomics levels, (4) at the genes level, (5) at the proteins level, (6) at metabolites level. Reported genes, proteins and molecules denote affected compounds or are used to bridge the pathways; upward arrows denote gene induction, protein and metabolite production; downward arrowdenote gene down regulation, protein and metabolite consumption.

Figure 6: Mechanistic network of the APAP toxicity from in vivo analysis proposed by Ruepp et al. 2002

Figure 7: Mitochondrial activity analyzed by JC-1 in biochips in control and APAP treated cases after $48 \mathrm{~h}$ of culture; (A) Red/Green ratio; (B) fluorescent images used for the analysis

Figure 8: Biomarkers network reconstruction of the 1mM-APAP toxicity in the HepG2/C3A after 96h of cultures in the biochips coming from the comparison between biochip controls vs APAP-treated biochips. Downward arrows denote metabolites consumptions; upward arrows denote metabolites production 
Table 1: Cell production (+) and consumption (-) in $\mathrm{nmol} / \mathrm{h} / 10^{6}$ cells of the compounds detected by $\mathrm{H}-$ NMR and measured in the culture medium. The data represent the situation between $48 \mathrm{~h}$ and $96 \mathrm{~h}$ of cultures in plates or biochips(mean and SD, $n=3+9=12$ ), --- denotes data below the limit of ${ }^{1} \mathrm{H}-\mathrm{RMN}$ detection $(1 \mu \mathrm{M})$, ${ }^{*}$ denotes values measured by conventional biochemical assays and kits, ${ }^{* *}$ denotes products detected by MS/MS; $(\mu)$ denotes Arbitrary Unit AU, $£$ denotes data in $\mathrm{ng} / \mathrm{h} / 10^{6}$ cells 
Table 2: List of genes, proteins and metabolites affected by the microfluidic conditions when

\begin{tabular}{|c|c|c|c|c|}
\hline \multirow[t]{2}{*}{ Compounds } & \multicolumn{2}{|c|}{ Plate conditions } & \multicolumn{2}{|c|}{ Biochip conditions } \\
\hline & Control & APAP-1mM & Control & APAP-1mM \\
\hline 2-Hydroxybutyrate & $0,5 \pm 0.05$ & $0,55 \pm 0.06$ & $0,6 \pm 0.2$ & $1,8 \pm 0.5$ \\
\hline 3-Hydroxybutyrate & $0,03 \pm 0.03$ & $0,040 \pm 0.07$ & $2 \pm 1.8$ & $5 \pm 3$ \\
\hline 3-Methyl-2-oxovalerate & $0.5 \pm 0.07$ & $0.5 \pm 0.07$ & $0.7 \pm 0.3$ & $1.5 \pm 0.3$ \\
\hline Acetate & --- & --- & $2,4 \pm 1.2$ & $3 \pm 1$ \\
\hline Alanine & $29 \pm 3$ & $49 \pm 5$ & $7 \pm 2$ & $35 \pm 7$ \\
\hline Albumin ${ }^{* \pm}$ & $71 \pm 12$ & $140 \pm 30$ & $78 \pm 25$ & $140 \pm 40$ \\
\hline Ammoniac * & $37 \pm 8$ & & $46 \pm 22$ & \\
\hline Arginine & $-16 \pm 19$ & $-21,3 \pm 26$ & $-16 \pm 5$ & $-43 \pm 12$ \\
\hline Asparagine & $-2.0 \pm 0.7$ & $-1,84 \pm 0.7$ & $-3 \pm 0.7$ & $-6 \pm 2$ \\
\hline Aspartate & $-1.0 \pm 0.3$ & $-2,87 \pm 0.8$ & $1,6 \pm 0.3$ & $-2.0 \pm 0.3$ \\
\hline Choline & $-0,12 \pm 0.03$ & $0,11 \pm 0.02$ & $-0,6 \pm 0.2$ & $-1,1 \pm 0.2$ \\
\hline Citrate & $0,6 \pm 0.1$ & $1,18 \pm 0.2$ & $1,32 \pm 0.44$ & $1,7 \pm 0.4$ \\
\hline Creatine & $-0,044 \pm 0.008$ & $0,18 \pm 0.03$ & $-0,25 \pm 0.04$ & $-0,35 \pm 0.05$ \\
\hline Creatinine & $-0.11 \pm 0.03$ & $-0.07 \pm 0.01$ & $-0.4 \pm 0.07$ & $-1 \pm 0.1$ \\
\hline Cystine & $-0,83 \pm 0.09$ & $-0,82 \pm 0.09$ & $-1,7 \pm 0.3$ & $-4,6 \pm 1.5$ \\
\hline Ethylacetate & $17 \pm 7$ & $20 \pm 5$ & $-2.8 \pm 0.4$ & $9 \pm 3$ \\
\hline Formate & $11 \pm 1.5$ & $13 \pm 2$ & $12 \pm 7$ & $23 \pm 6$ \\
\hline Fructose & $-15 \pm 17$ & $-14 \pm 6$ & $-3,2 \pm 0.4$ & $-9 \pm 1$ \\
\hline Glucose & $-160 \pm 10$ & $-210 \pm 20$ & $-200 \pm 14$ & $-228 \pm 35$ \\
\hline Glucose * & $-138 \pm 20$ & $-191 \pm 40$ & $-172 \pm 30$ & $-283 \pm 60$ \\
\hline Glutamate & $6,7 \pm 0.9$ & $6,5 \pm 0.8$ & $17 \pm 6$ & $31 \pm 6$ \\
\hline Glutamine & $-29 \pm 4$ & $-35 \pm 5$ & $-66 \pm 29$ & $-93 \pm 23$ \\
\hline Glutamine * & $-16 \pm 5$ & & $-66 \pm 20$ & \\
\hline Glycine & $3,2 \pm 0.3$ & $5,5 \pm 0.8$ & $6 \pm 2$ & $9 \pm 2$ \\
\hline GSH-APAP $^{* *, \mu}$ & -- & -- & --- & $3 \pm 1$ \\
\hline Histidine & $-0,8 \pm 0.1$ & $-0,35 \pm 0.04$ & $-1,5 \pm 0.13$ & $-2,9 \pm 0.4$ \\
\hline Isoleucine & $-4,4 \pm 0.4$ & $-3,97 \pm 0.4$ & $-6,6 \pm 0.4$ & $-11,7 \pm 1.3$ \\
\hline Lactate & $302 \pm 32$ & $429 \pm 46$ & $349 \pm 94$ & $277 \pm 61$ \\
\hline Leucine & $-4,8 \pm 0.5$ & $-5,2 \pm 0.7$ & $-7,4 \pm 1.4$ & $-15 \pm 3$ \\
\hline Lysine & $-0,37 \pm 0.09$ & $0,24 \pm 0.05$ & $-1,4 \pm 0.4$ & $-3,1 \pm 0.5$ \\
\hline Methionine & $-0,97 \pm 0.11$ & $-0,87 \pm 0.1$ & $-1,8 \pm 0.2$ & $-2,8 \pm 0.4$ \\
\hline Methanol & $0.6 \pm 0.4$ & $0.87 \pm 0.4$ & $0.07 \pm 0.05$ & $0.5 \pm 0.1$ \\
\hline Methylguanidine & $-0.5 \pm 0.1$ & $-0.4 \pm 0.1$ & $-1 \pm 0.3$ & $-2.5 \pm 0.4$ \\
\hline myo-Inositol & $0,67 \pm 0.07$ & $1,42 \pm 0.2$ & $-0,8 \pm 0.1$ & $0,78 \pm 0.09$ \\
\hline Ornithine & $9,4 \pm 1$ & $13 \pm 3$ & $12 \pm 10$ & $22 \pm 16$ \\
\hline Phenylalanine & $-1,04 \pm 0.1$ & $-1,3 \pm 0.1$ & $-2,9 \pm 0.3$ & $-4,3 \pm 0.5$ \\
\hline Proline & $8,6 \pm 0.8$ & $12,6 \pm$ & $6 \pm 2$ & $12 \pm 2$ \\
\hline Pyroglutamate & $-3 \pm 0.5$ & $-3 \pm 0.4$ & $4 \pm 0.7$ & $8 \pm 1$ \\
\hline Pyruvate & $-17 \pm 3$ & $-16 \pm 4$ & $-11 \pm 3$ & $-48 \pm 10$ \\
\hline Serine & $2,6 \pm 0.6$ & $6 \pm 1$ & $1,1 \pm 0.3$ & $5 \pm 1$ \\
\hline Succinate & $-1,4 \pm 1.2$ & $-1,7 \pm 1.2$ & $0,4 \pm 0.1$ & $-2 \pm 1$ \\
\hline Sult-APAP $^{* *}$ & --- & $44 \pm 2$ & --- & $77 \pm 18$ \\
\hline Threonine & $1,31 \pm 0.16$ & $2,54 \pm 0.2$ & $-0,92 \pm 0.09$ & $-2,4 \pm 0.3$ \\
\hline Tryptophan & $0,23 \pm 0.03$ & $0,44 \pm 0.06$ & $0,06 \pm 0.003$ & $0,57 \pm 0.05$ \\
\hline Tyrosine & $0,62 \pm 0.075$ & $2,7 \pm 0.3$ & $-0,7 \pm 0.1$ & $1,50 \pm 0.2$ \\
\hline Urea* & --- & -- & --- & -- \\
\hline UGT-APAP $^{* *}$ & --- & --- & --- & --- \\
\hline Valine & $-0,34 \pm 0.03$ & $1,6 \pm 0.2$ & $-2,3 \pm 0.1$ & $-3,0 \pm 0.4$ \\
\hline
\end{tabular}

compared to plate cultures and involved in the network reconstruction of Figs 2 and 3 . Underlined genes were confirmed by RTqPCR (Prot et al., 2011a) 


\begin{tabular}{|c|c|c|c|c|}
\hline \multicolumn{2}{|c|}{$\begin{array}{l}\text { Networks and } \\
\text { pathways }\end{array}$} & CORROLATED GENES & $\begin{array}{l}\text { Corrolated } \\
\text { Proteins }\end{array}$ & $\begin{array}{l}\text { Corrolated } \\
\text { metabolites }\end{array}$ \\
\hline \multirow{8}{*}{ 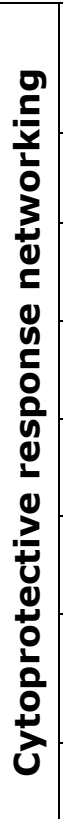 } & NFR2 pathway & $\begin{array}{l}\text { AKR, AKT, CAT, CBR1, CYP 1A1, CYP1A2, EPHX1, } \\
\text { FTH1, FTL, GCLM, GPX2, GSR, GST, HO-1, } \\
\text { HSP90, KEAP1, MEK1/2, NQO1,PI3K, PRDX1, } \\
\text { SOD, SQTSM1, STIP1, SULT1A, UGT, VCP, TXN }\end{array}$ & $\begin{array}{l}\text { ftl, actin, gsto1, sult1a, } \\
\text { aldh1a1, g6pd, hsp90, } \\
\text { pdia }\end{array}$ & \\
\hline & $\begin{array}{l}\text { Actin regulation } \\
\text { pathway }\end{array}$ & $\begin{array}{l}\text { ARPC, CDC42, CFL1, GSN, PAK1/7, PI3K } \\
\text { PIP4K2B , PFN2, SSH2, VAV2, WAS , WASF2 }\end{array}$ & actin & \\
\hline & $\begin{array}{l}\text { Glutathione } \\
\text { pathway }\end{array}$ & GCLM, GGT, GPX2, GSR, GST, IDH1, ODC1 PEPN & gsto1, g6pd & $\begin{array}{l}\text { Glycine, Glutamate, } \\
\text { Cystine, Ornithine }\end{array}$ \\
\hline & $\begin{array}{l}\text { Methionine } \\
\text { pathway }\end{array}$ & $\begin{array}{c}\text { ADI1, AMD1, CBS, GOT2, MAT1A, MAT2B, MTAP, } \\
\text { SRM }\end{array}$ & & $\begin{array}{l}\text { Cystine, Serine, } \\
\text { Methionine, 2- } \\
\text { Hydroxybutyrate }\end{array}$ \\
\hline & $\begin{array}{l}\text { Serine glycine } \\
\text { threonine } \\
\text { pathway }\end{array}$ & $\begin{array}{c}\text { ALAS1, AOC3, CBS, DLD, GLYCTK, MAOB, } \\
\text { PSAT1, SARDH, SHMT1 }\end{array}$ & $\begin{array}{l}\text { D3-phosphoglycerate } \\
\text { dehydrogenase, strap }\end{array}$ & $\begin{array}{l}\text { Serine, Glycine, } \\
\text { Threonine }\end{array}$ \\
\hline & $\begin{array}{l}\text { Glutamate } \\
\text { pathway }\end{array}$ & ALDH5A1, CAD, GAD1, GCLM, GSR , NADGK & aldh5a1 & $\begin{array}{l}\text { Glutamate, } \\
\text { Glutamine } \\
\text { Amino acid }\end{array}$ \\
\hline & $\begin{array}{l}\text { Arginine/proline } \\
\text { pathway }\end{array}$ & $\begin{array}{c}\text { ACY1, ADC, AGMAT1, ALDH1B1, ARG1, GOT2, } \\
\text { MAOB, NOS , ODC1, PYCR, SMOX, SMS, SPR, } \\
\text { SRM }\end{array}$ & $\begin{array}{l}\text { aldh1b1, aldh1a1 } \\
c k b\end{array}$ & $\begin{array}{l}\text { OrnithineArginine } \\
\text { Proline } \\
\text { Creatine/Creatinine } \\
\text { Glutamine Glutamate } \\
\end{array}$ \\
\hline & $\begin{array}{l}\text { PXR/RXR } \\
\text { pathway }\end{array}$ & 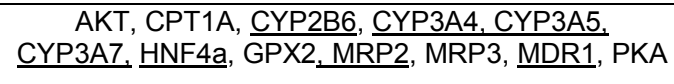 & 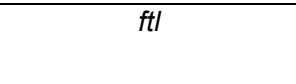 & \\
\hline \multirow{8}{*}{ 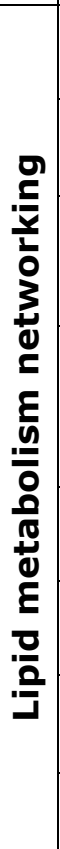 } & PPAR signaling: & $\begin{array}{c}\text { PPARG, PLTP,DBI, FADS2, SCL27A4, CPT1A, } \\
\text { EHHADH, ACADM }\end{array}$ & $\begin{array}{l}\text { acat1, acat2, aldh1a1, } \\
\text { aldh1b1, hmgcs1 }\end{array}$ & Succinate \\
\hline & $\begin{array}{l}\text { Fatty acid } \\
\text { biosynthesis and } \\
\text { metabolism }\end{array}$ & $\begin{array}{c}\text { ACACA,ACADM, ACADSB, ACAT1, ALDH, CPT1A, } \\
\text { EHHADH, FASN, HADHA, MCAT, OXSM }\end{array}$ & acat1, acat2 & \\
\hline & Lipid metabolism & $\begin{array}{c}\text { GLYCTK, ALDH1B1, AKR1A1, , DGK, , LIPA, GLA, } \\
\text { GPD1, GPD1L, GPAM, AGPAT6, AGPAT3, } \\
\text { PLD1,DGKZ, PEMT,PTDSS (1,2), LCAT, } \\
\text { LPCAT,PCYT1, LYPLA2, CHKA }\end{array}$ & & $\begin{array}{l}\text { Glycine, Serine, } \\
\text { Threonine }\end{array}$ \\
\hline & $\begin{array}{c}\text { Steroid } \\
\text { biosynthesis }\end{array}$ & $\begin{array}{l}\text { FDFT1, SQLE, ACAT1, LSS TM7SF2, SC4MOL, } \\
\text { NSDHL, HSD17B7, EBP, SC5DL, LIPA, STS, } \\
\text { AKR1C (2,3,4), CYP21A2, CYP1A, CYP3A4, } \\
\text { CYP3A5, CYP 3A7, CYP3A43, CYP19A1, COMT, } \\
\text { UGT1A1, UGT2B7 }\end{array}$ & acat1, acat2 & \\
\hline & Ketone pathway & ACAT1, BDH1, HMGCS1 & acat1, hmgcs1 & 3-hydroxybutyrate \\
\hline & $\begin{array}{l}\text { Butanoate } \\
\text { pathway }\end{array}$ & $\begin{array}{c}\text { ACSM3, AKR1B10,ALDH1B1, ALDH5A1, BDH1, } \\
\text { EHHADH, GAD1, HMGCS1 }\end{array}$ & $\begin{array}{l}\text { acat1, aldh1b1, } \\
\text { hmgcs1 }\end{array}$ & \\
\hline & $\begin{array}{l}\text { Alanine/aspartate } \\
\text { pathway }\end{array}$ & $\begin{array}{l}\text { ADSSL1, ALDH4A1, ALDH5A1, CAD, GAD1, } \\
\text { GLUD1, GOT2 }\end{array}$ & aldh5a1 & $\begin{array}{c}\text { Alanine } \\
\text { Aspartate Succinate, } \\
\text { Glutamate Glutamine }\end{array}$ \\
\hline & $\begin{array}{l}\text { PXR/RXR } \\
\text { pathway }\end{array}$ & $\begin{array}{c}\text { AKT, CPT1A, CYP2B6, CYP3A4, CYP3A5, } \\
\text { CYP3A7, HNF4a, GPX2, MRP2, MRP3, MDR1, PKA }\end{array}$ & $f t l$ & \\
\hline \multirow{4}{*}{ 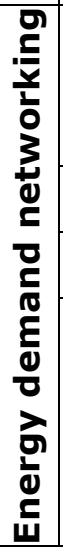 } & $\begin{array}{c}\text { Insulin } \\
\text { pathway/Glucose } \\
\text { homestasis }\end{array}$ & $\begin{array}{c}\text { CALM1, PYG1, GSK3B, PPP1CA, PPP1R3B , } \\
\text { PPP1R3D ,PDE3B, PKA ,GYS, SOCS ,INS, INSR } \\
\text { RHOQ, EXOC7,CRKL, EXO70, RAPGEF1,CBL, } \\
\text { SH2B2 TRIP10,PDK,AKT1,APKC, } \\
\text { PI3K,GK,FAS,ACC }\end{array}$ & & $\begin{array}{l}\text { Glucose, Fructose, } \\
\text { Lactate, Myo inositol }\end{array}$ \\
\hline & TCA cycle & $\begin{array}{c}\mathrm{PC}, \mathrm{MDH} 1, \mathrm{ACLY}, \mathrm{IDH}, \mathrm{IDH} 3 \mathrm{~A}, \mathrm{OGDH}, \mathrm{DLD}, \mathrm{ACO} 2, \\
\text { DLST }\end{array}$ & & $\begin{array}{c}\text { Citrate, Pyruvate, } \\
\text { Succinate }\end{array}$ \\
\hline & $\begin{array}{l}\text { Pyruvate } \\
\text { pathway }\end{array}$ & PC, MDH1, DLD,ACSS2,ACYP1, ACAT1,ACACA & $\begin{array}{c}\text { dlat,acat1,eno1, eno2, } \\
\text { tpi1,gls, aldh5a1, }\end{array}$ & $\begin{array}{l}\text { Pyruvate, Lactate, } \\
\text { Acetate,Formate }\end{array}$ \\
\hline & $\begin{array}{l}\text { Glutamine } \\
\text { pathway }\end{array}$ & GLS, GAD1, ALDH5A1 & g/s, adlh5a1 & $\begin{array}{l}\text { Glutamine, } \\
\text { Glutamate }\end{array}$ \\
\hline
\end{tabular}



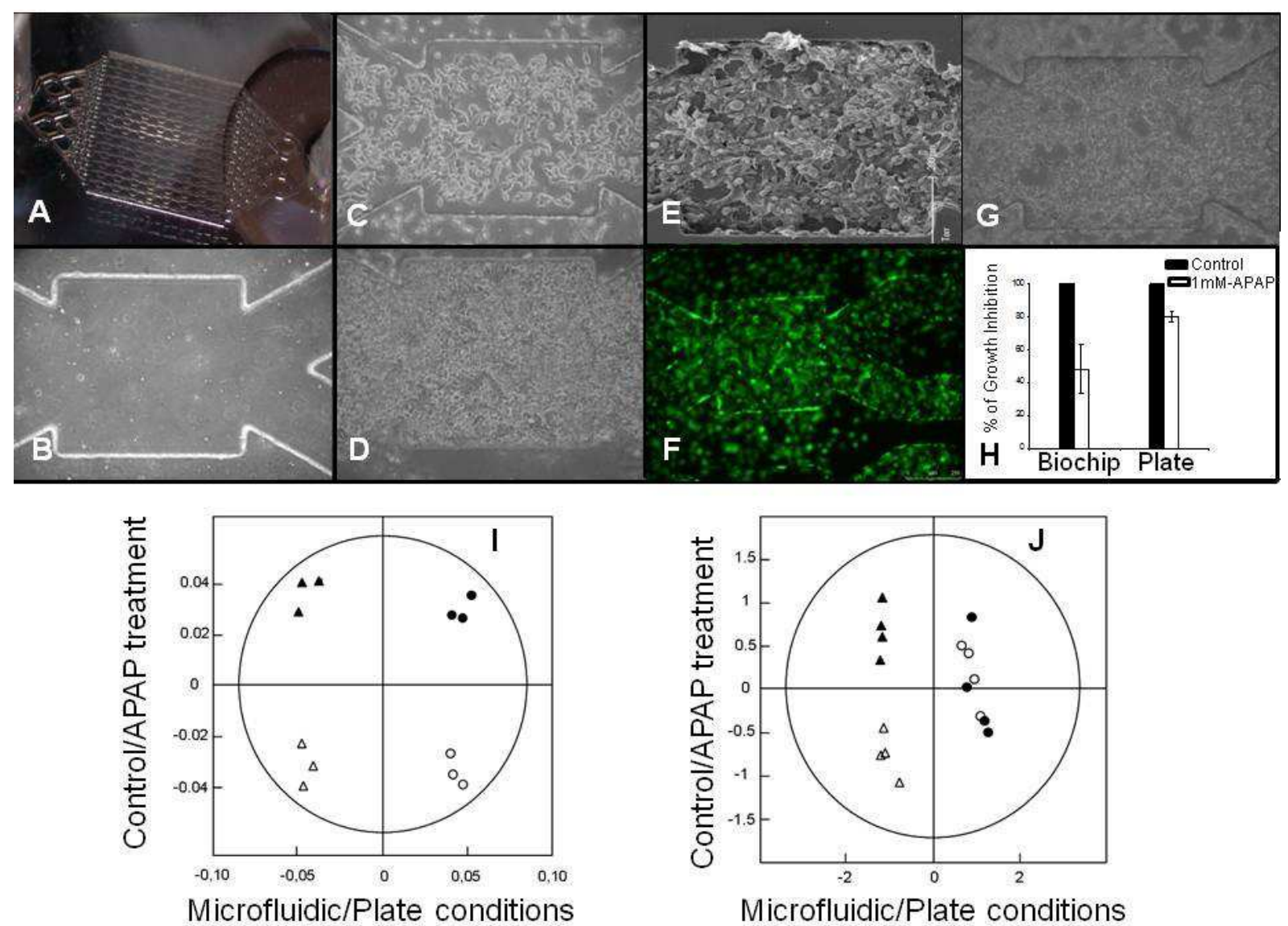

Figure 1: (A) Microfluidic PDMS network; (B) Cell chamber before cell inoculation; (C) Cell after adhesion; (D) Cell after 96h of cultures without APAP; (E) SEM view of the cell multilayers in the biochip after $96 \mathrm{~h}$ of culture without APAP; (F) viability of the cells after $96 \mathrm{~h}$ of culture without APAP ; (G) Cells after $96 \mathrm{~h}$ of cultures including $72 \mathrm{~h}$ of APAP treatment; $(\mathrm{H})$ Cell number decreases in biochip and plate with $1 \mathrm{mM}$ of APAP after $96 \mathrm{~h}$ of cultures including $72 \mathrm{~h}$ of treatment; (I) Results of the PCA of the transcriptomic analysis; $(\mathrm{J})$ Results of the PCA of the proteomic analysis; circles denotes plate data, triangles denote biochip data, black symbols are control data, white symbols are APAP data 


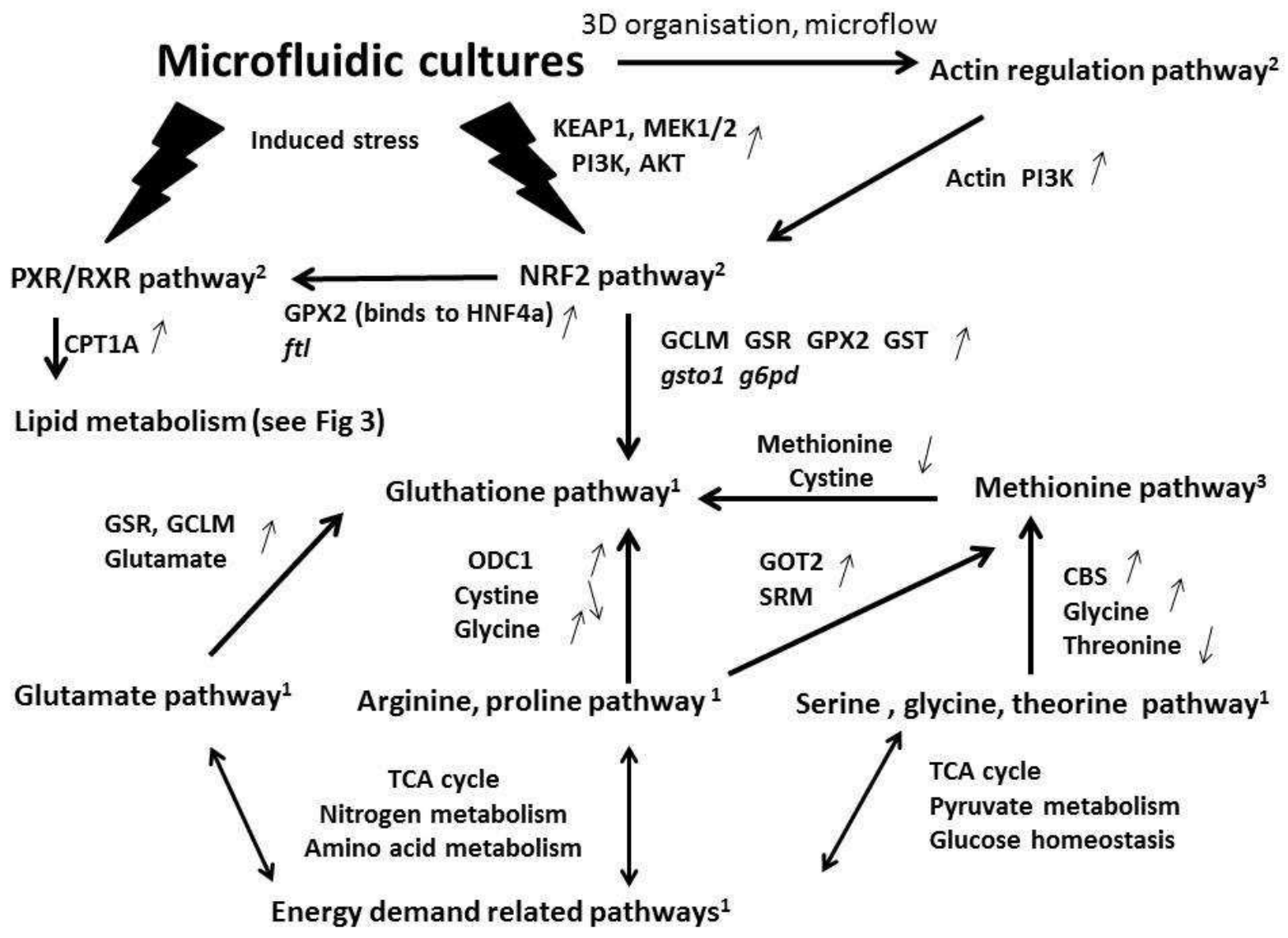

Figure 2: Network reconstruction according to the integration of the transcriptomic, proteomic and metabolomic profiles after $96 \mathrm{~h}$ of cultures describing the HepG2/C3A response to the microfluidic biochip conditions. Superscripts denote information from table 2 and extracted at (1) the genes, proteins and metabolites levels, (2) at the gene and protein levels, (3) at the genes and metabolites levels, (4) at the genes level. Reported genes, proteins and metabolites are common element used to bridge the pathways; upward arrows denote gene induction, protein and metabolite production;downward arrows denote gene down regulation, protein and metabolite consumption. Capital letters (e.g. CBS ...) denote affected genes in the pathway, small italic letters denotes proteins (e.g. strap...) related to the pathway. 


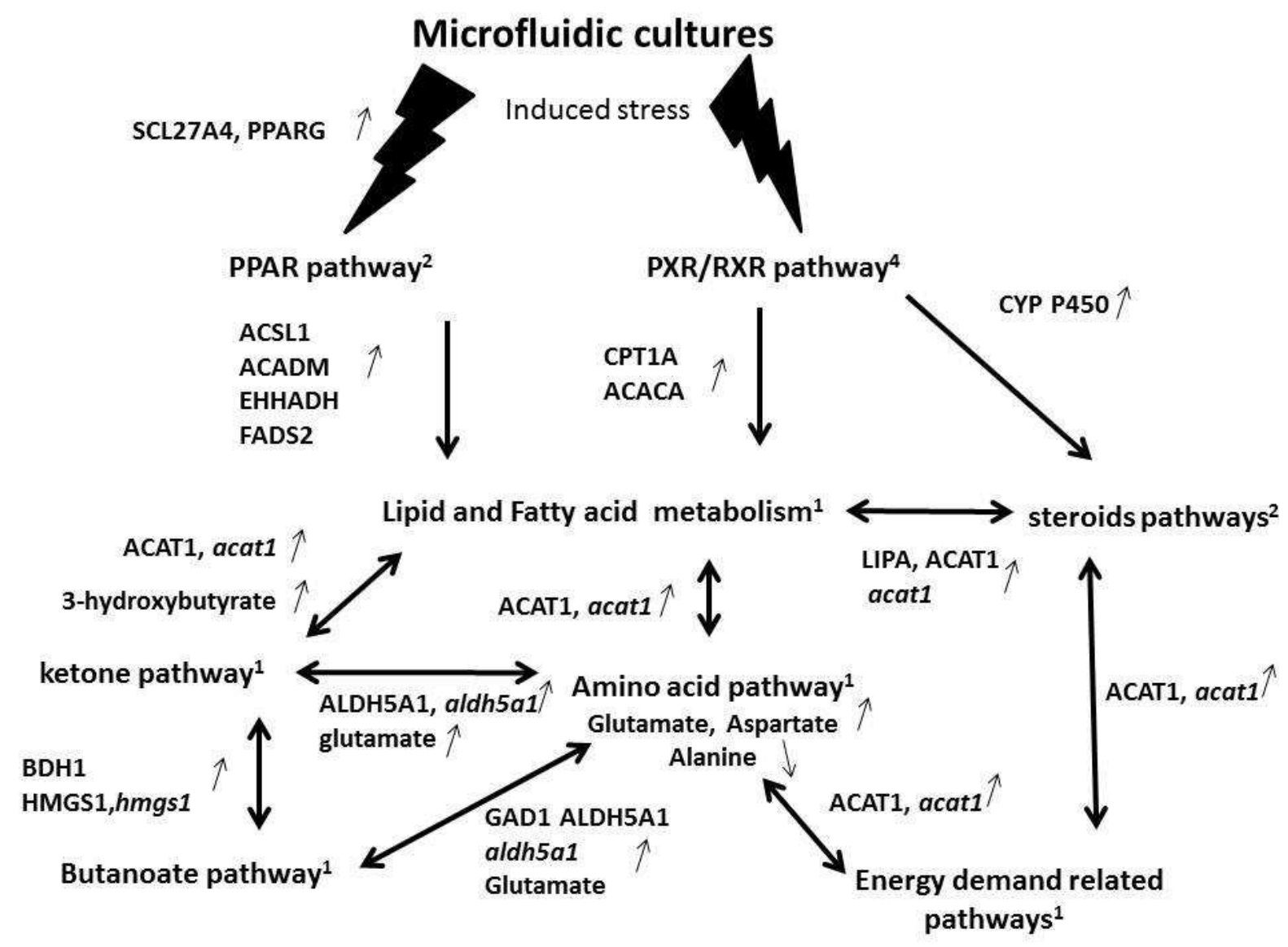

Figure 3: Network reconstruction according the integration of the transcriptomic, proteomic and metabolomic profiles after $96 \mathrm{~h}$ of culture of the HepG2/C3A in microfluidic biochips focusing on the lipids, fatty acids and steroids metabolism. Superscripts denote information from table 2 extracted at (1) the genes, proteins and metabolites levels, (2) at the gene and protein levels, (3) at the genes and metabolites levels, (4) at the genes level. Reported genes, proteins and metabolites are common element used to bridge the pathways; upward arrows denote gene induction, protein and metabolite production; downward arrowsdenote gene down regulation, protein and metabolite consumption. 


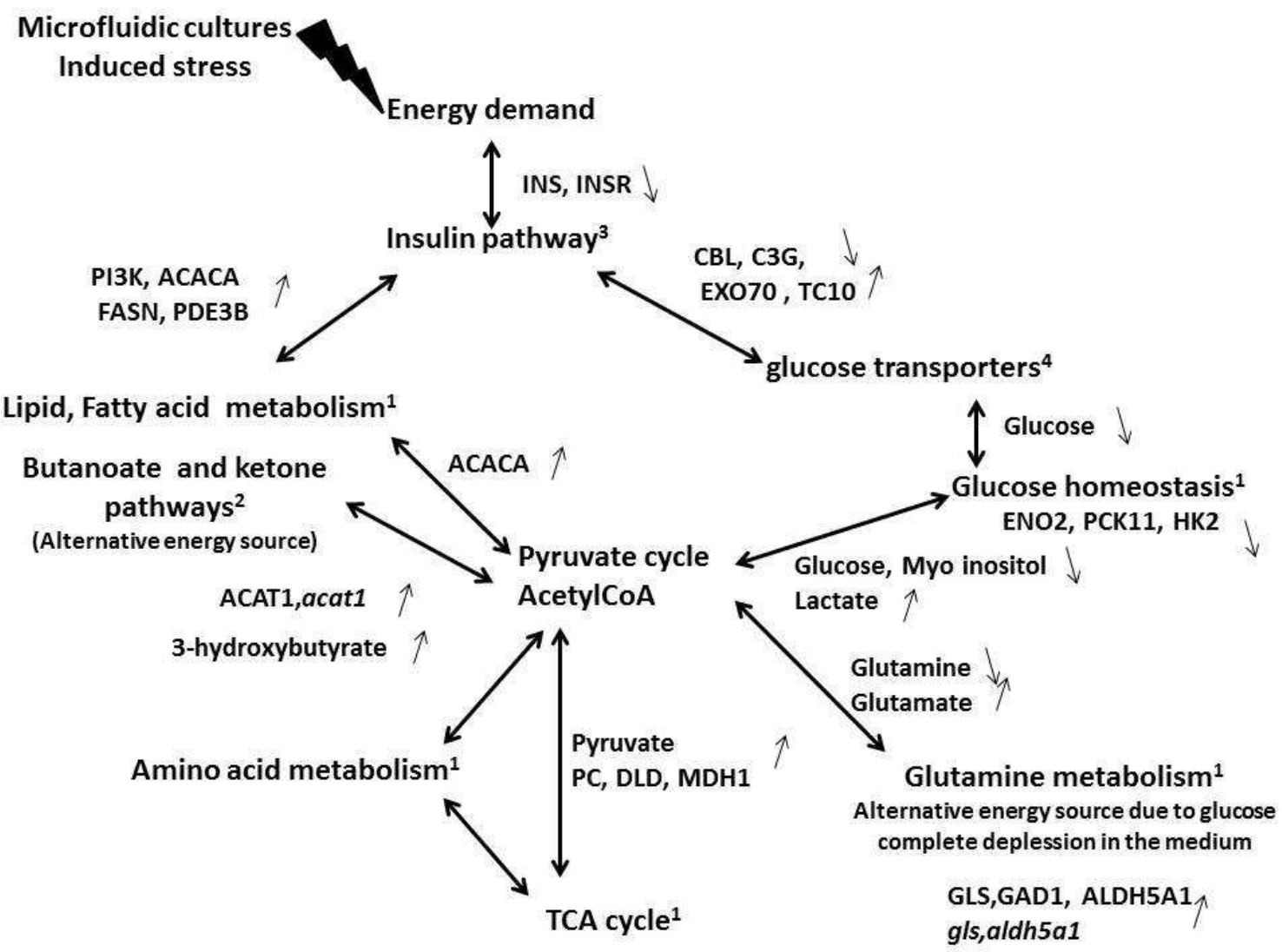

Figure 4: Network reconstruction according the integration of the transcriptomic, proteomic and metabolomic profiles after $96 \mathrm{~h}$ of culture and related to the HepG2/C3A energy demand. Superscripts denote information from table 2 extracted at (1) the genes, proteins and metabolites levels, (2) at the gene and protein levels, (3) at the gene and metabolites levels, (4) at the genes level. Reported genes, proteins and molecules are common element used to bridge the pathways; upward arrows denote gene induction, protein and metabolite production; downward arrowsdenote gene down regulation, protein and metabolite consumption. 


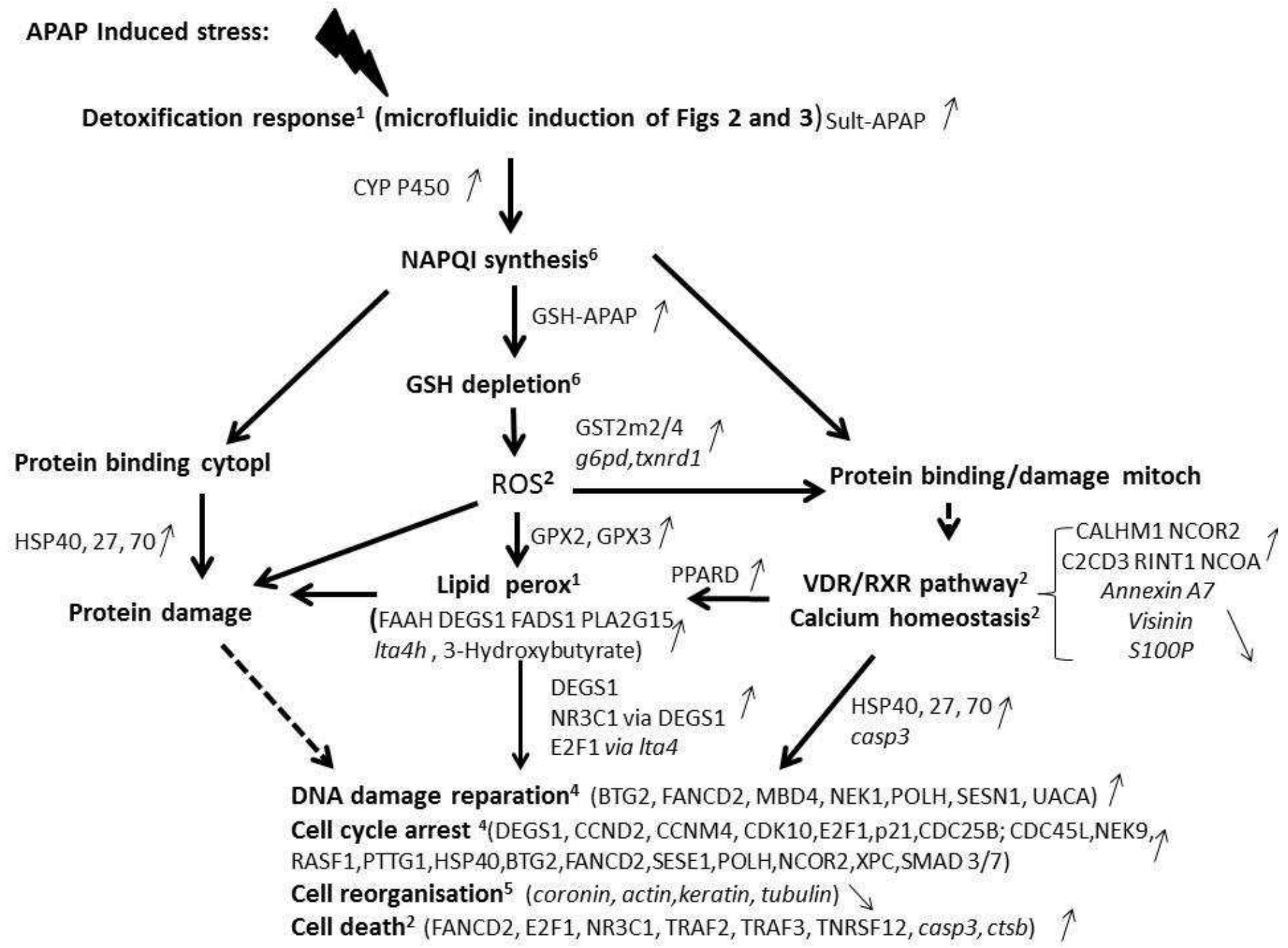

Figure 5: Mechanistic network reconstruction of the 1mM-APAP toxicity in the HepG2/C3a after 96h of culture in biochip (based on the in vivo representation of Ruepp et al. 2002 presented in Fig 6); Superscripts denote information confirmed at (1) the genes, proteins and metabolomics levels, (2) at the gene and protein levels, (3) at the gene and metabolomics levels, (4) at the genes level, (5) at the proteins level, (6) at metabolites level. Reported genes, proteins and molecules denote affected compounds or are used to bridge the pathways; upward arrows denote gene induction, protein and metabolite production; downward arrowdenote gene down regulation, protein and metabolite consumption. 


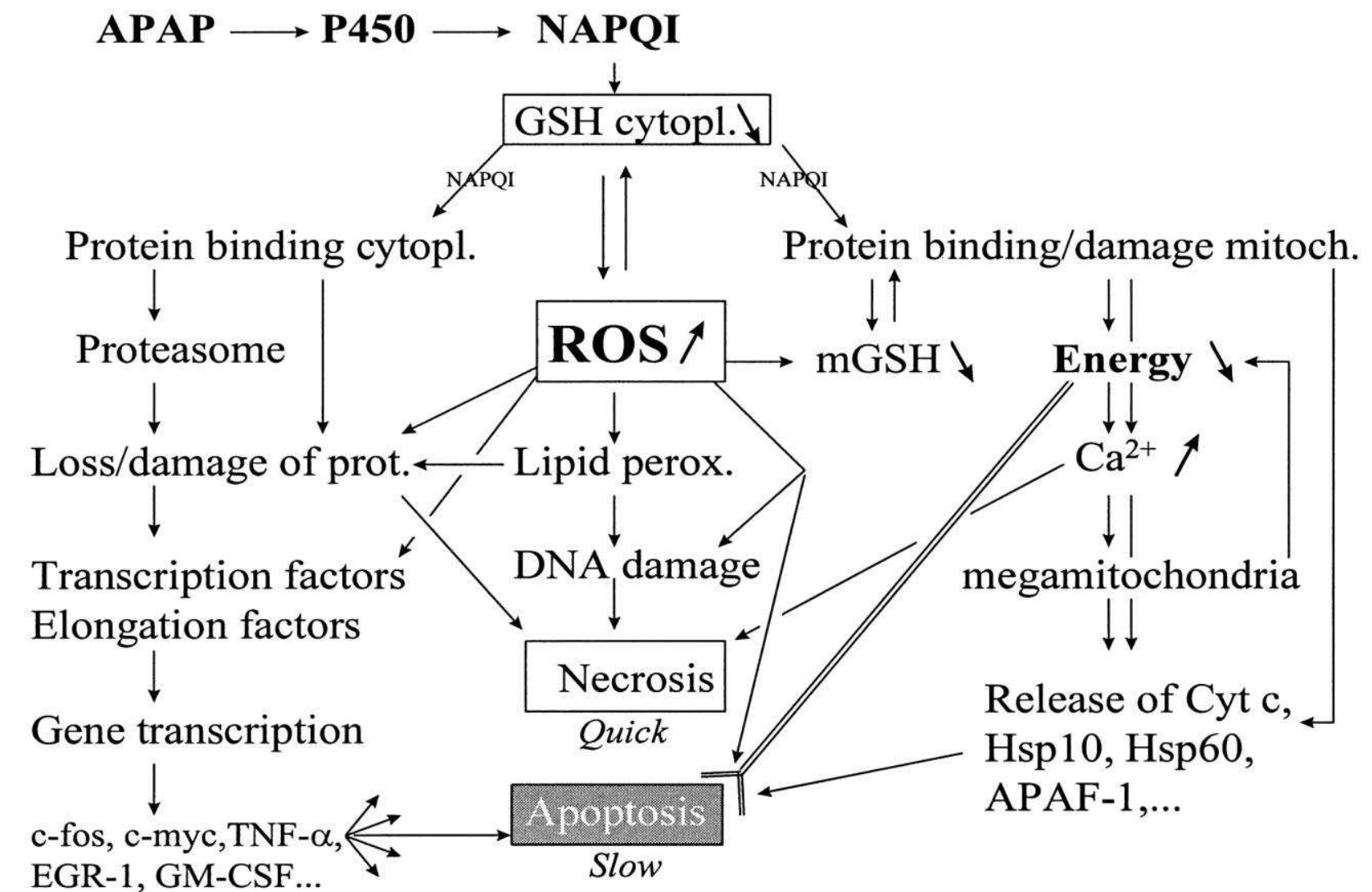

Figure 6: Mechanistic network of the APAP toxicity from in vivo analysis proposed by Ruepp et al. 2002 (figure extracted from Ruepp et al.) 
A

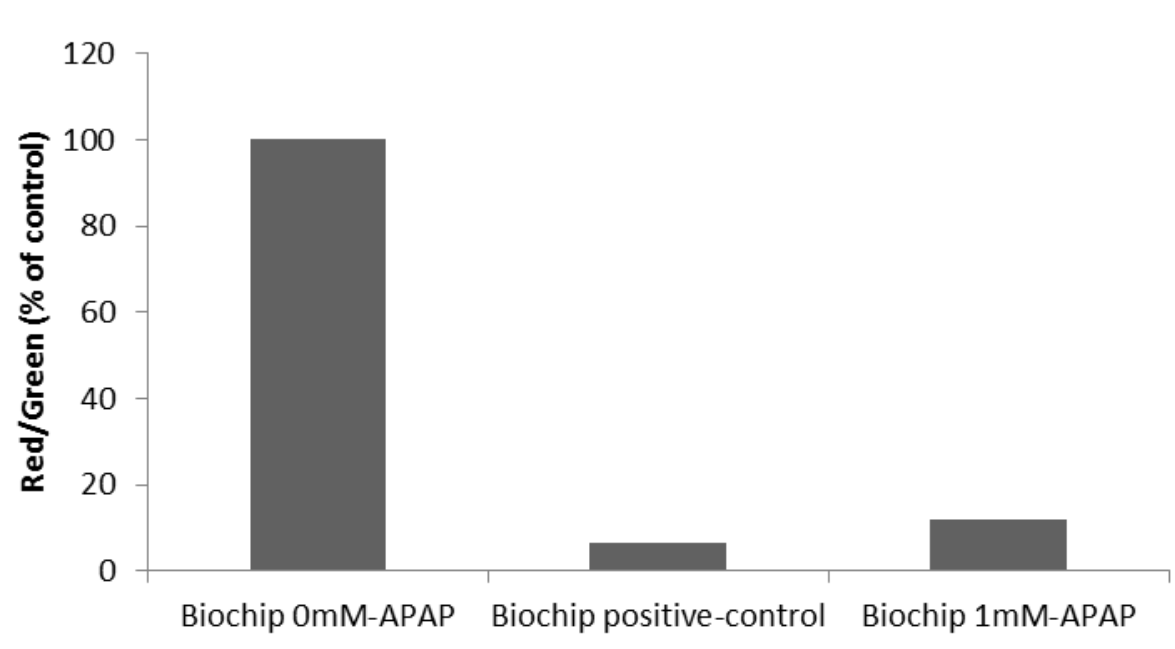

B

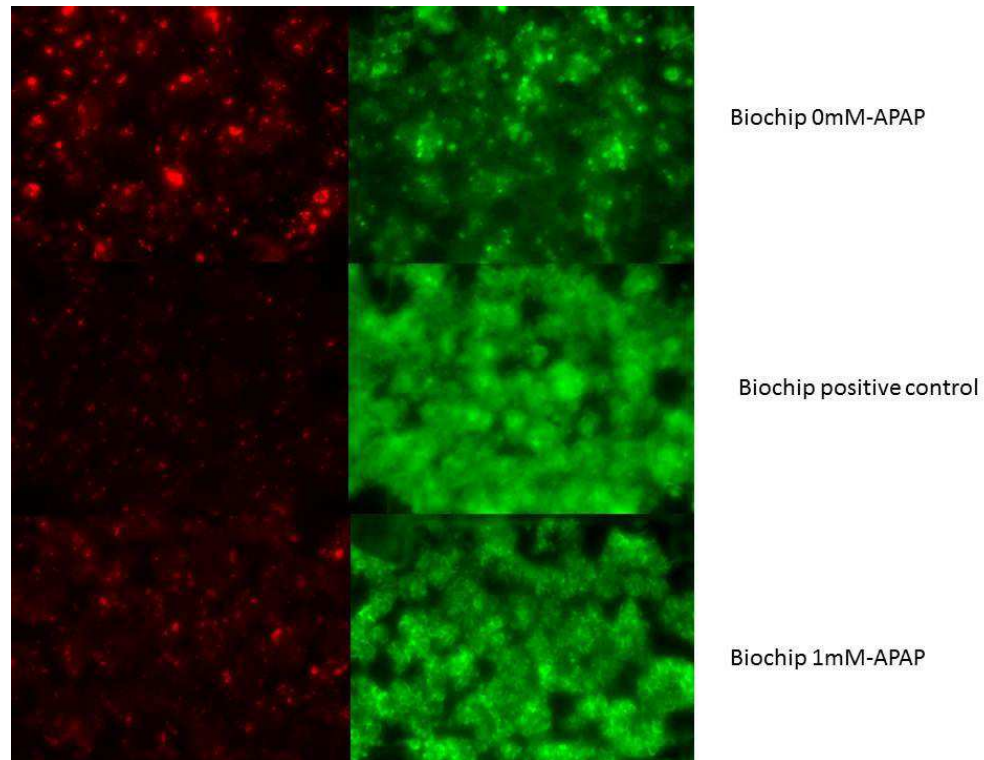

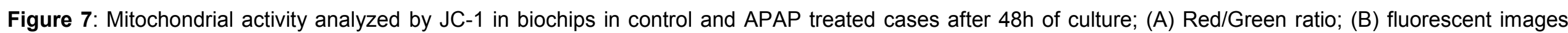
used for the analysis 


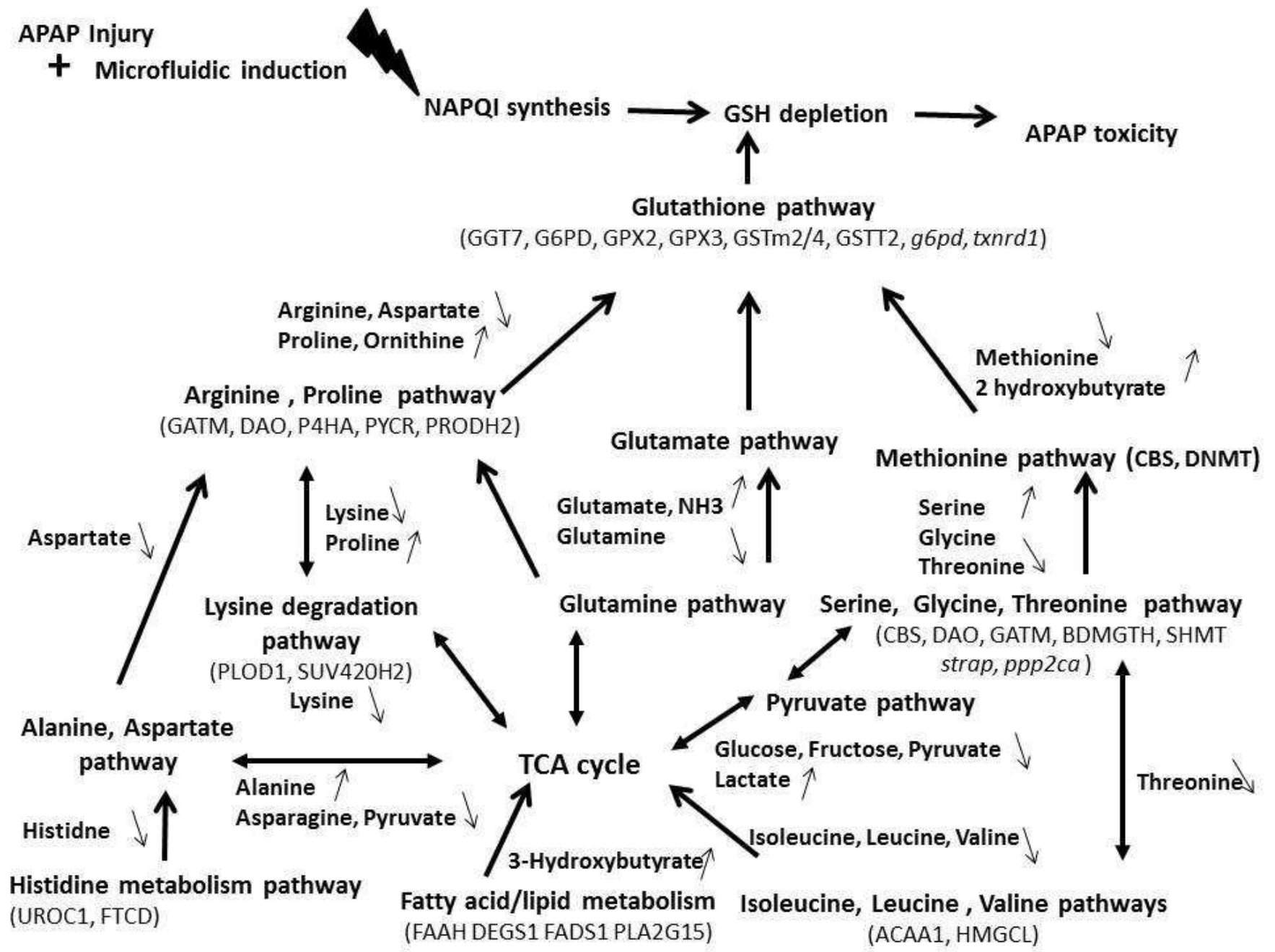

Figure 8: Biomarkers network reconstruction of the 1mM-APAP toxicity in the HepG2/C3A after $96 \mathrm{~h}$ of cultures in the biochips coming from the comparison between biochip controls vs APAP-treated biochips. Downward arrows denote metabolites consumptions; upward arrows denote metabolites production 